\title{
Reggio Emilia-ilhamlı okullarda kaynaştırma eğitimi: Meta-etnografik bir araştırma
}

\author{
Inclusive education in Reggio Emilia-inspired preschools: A meta- \\ ethnographic study
}

Hatice Zeynep Inan ${ }^{1}$

\begin{abstract}
Makale Geçmişi
Geliş : 3 Temmuz 2020

Düzeltme : 21 Eylül 2020

Kabul : 1 Aralık 2020
\end{abstract}

\section{Makale Türü}

Araștırma Makalesi
Article History

Received : 3 July 2020

Revised : 21 September 2020

Accepted : 1 December 2020

Article Type

Research Article
Öz: Türkiye'de son yıllarda eğitimcilerin ilham aldığı Reggio Emilia yaklaşımına dair halen pek çok merak edilen konu bulunmaktadır. Özellikle merak konusu olan bir nokta da, özel gereksinimli çocukların bu okullarda nasıl bir kaynaştırma eğitimine tabi olduğudur. Bu meta-etnografik araştırmanın amacı, tipik gelişim gösteren çocukların devam ettiği Reggio Emilia sınıflarında, özel gereksinimli çocukların nasıl kaynaştırıldığını ortaya koyan çalışmaları, meta-etnografi yöntemine uygun olarak incelemek ve sentezlemektir. Bu çalışmada, Reggio Emilia yaklaşımının sosyal-yapılandırmacı yapısına uygun olarak, nitel araştırma deseninden yararlanılmıştır. Bu araştırmada Noblit ve Hare'nin (1988) yedi basamaklı meta-etnografi metodu kullanılmıştır. Reggio Emilia yaklaşımını esas almış okul öncesi eğitim kurumlarında özel hakları olan çocuklara dair yapılan çalışmalar incelendiğinde, en yoğun olarak üstünde durulan prensiplerden en az konuşulan prensiplere doğru şu sıranın izlendiği bulunmuştur: 1-İlişkiler prensibi; 2-Çocuk imaj1; 3-Öğretmenin rolü; 4-Proje; 5-Çevrenin rolü; ; 6-Dokümantasyon. Bulgular, sonuç/tartışma ve öneriler detaylı olarak sunulmuştur.

Anahtar Kelimeler: Okul Öncesi Ĕgitim, Meta-etnografi, Özel Hakları Olan Çocuk, Reggio Emilia, Kaynaştırma Eğitimi, Kapsayıcılık, Özel Gereksinimli Çocuklar

Abstract: In recent years, educators in Turkey started to be inspired by Reggio Emilia approach and curious about some subjects related to Reggio Emilia approach. One of the topics people are curious about is the inclusive education of children with special needs in Reggio Emilia preschools. The purpose of this meta-ethnographic research is to examine and synthesize the studies that reveal how children with special needs are included in general education classrooms in Reggio Emilia preschools. In this study, qualitative research design is used in accordance with the social-constructivist structure of Reggio Emilia approach. In this research, seven-step meta-ethnography method of Noblit and Hare (1988) is used. When the studies on children with special rights in preschools inspired by Reggio Emilia approach are examined, the following sequence emerges from the most emphasized principles to the least emphasized ones: 1-Relationships; 2-Child image; 3-Teacher's role; 4-Project; 5-Environment's role; 6Documentation. Results, conclusion/discussion and recommendations are presented in detail.

Keywords: Early Childhood Education, Meta-ethnography, Children with Special Rights, Reggio Emilia, Inclusive Education, Inclusion, Children with Special Needs 


\section{SUMMARY}

\section{Introduction}

In recent years, educators started to be inspired by Reggio Emilia approach and curious about some subjects related to Reggio Emilia approach. One of the topics people are curious about is the inclusive education of children with special needs in Reggio Emilia preschools. However, there is no single study on such issue in Turkey.

Every child has the right to receive a good education according to the founder of Reggio Emilia approach, Loris Malaguzzi (1994). Children with special needs also have the right to receive good education in general education classrooms with their peers with typical development. The purpose of this meta-ethnographic research is to examine and synthesize the studies that reveal how children with special needs are included in general education classrooms in Reggio Emilia preschools. Accordingly, answers are sought for the following questions:

1-Which of the six main principles of Reggio Emilia approach (child image, teacher's role, project, role of the environment, documentation, relationships) do inclusive education research studies fit into?

2-How do these studies fit into Reggio Emilia principles?

\section{Method}

In this study, qualitative research design is used in accordance with the social-constructivist structure of Reggio Emilia Approach and the meta-ethnography method is chosen among the qualitative research methods and techniques because the meta-ethnography method allows to interpret qualitative research and make cumulative synthesis through induction (Campbell et al., 2011; Ellis, 2009; Elsevier, 2020; Hughes \& Noblit, 2017; Noblit \& Hare, 1988; Noyes, 2006). In this research, seven-step meta-ethnography method of Noblit and Hare (1988) is adapted according to the theme of the research, namely "Inclusive education in Reggio Emilia and Reggio Emilia-inspired preschools” (see Figure 1). 


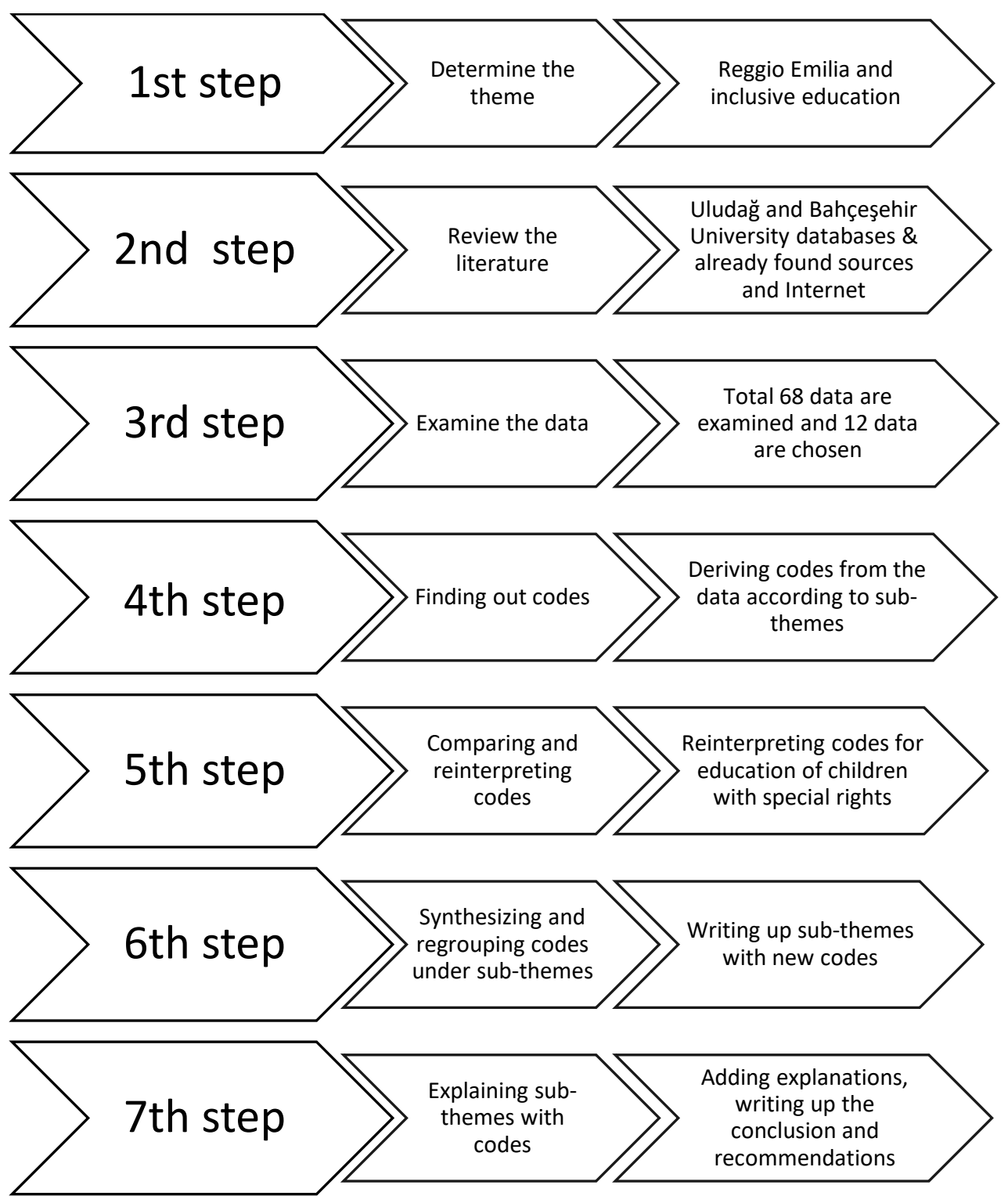

Figure 1. Sythesizing inclusive education in seven steps of meta-ethnography

Table 1 presents the used databases/sources, the keywords and the full information about the data, which made used of qualitative research methods and are chosen for the current research. 
Table 1. Databases/sources, keywords and full information about the data

\begin{tabular}{|c|c|c|}
\hline $\begin{array}{l}\text { Databases/ } \\
\text { Sources }\end{array}$ & Keywords & Data \\
\hline $\begin{array}{l}\text { *Bursa Uludağ } \\
\text { University and } \\
\text { Bahçeşehir } \\
\text { University } \\
\text { libraries online } \\
\text { catalogs, (e.g., } \\
\text { Ebscohost: } \\
\text { e-dissertations, } \\
\text { e-books, } \\
\text { e-journals, } \\
\text { Turkish } \\
\text { e-journals) } \\
\text { *Already found } \\
\text { sources } \\
\text { *Internet }\end{array}$ & $\begin{array}{l}\text { *Reggio Emilia } \\
\text { *Inclusion } \\
* \text { Special needs } \\
\text { *Special rights } \\
\text { *Special } \\
\text { education } \\
\text { *Disability }\end{array}$ & $\begin{array}{l}\text { *Cox, L. (2017). Children with special rights in Reggio Emilia - A story of the } \\
\text { possible. International Educator, 31(4), 10-33. } \\
\text { *Edmiaston, R. \& Fitzgerald, L.M. (2000). How Reggio Emilia encourages } \\
\text { inclusion. Educational Leadership 58(1), 66. } \\
\text { *Gilman, S. (2007). Including the child with special needs: Learning from } \\
\text { Reggio Emilia. Theory into Practice, 46(1), 23-31. } \\
\text { *Hong, S.B. \& Shaffer, L.S. (2015). Inter-professional collaboration: Early } \\
\text { childhood educators and medical therapist working within a collaboration. } \\
\text { Journal of Education and Training Studies, 3(1), 135-145. } \\
\text { *Hong, S.B., Shaffer, L., Han, J. (2017). Reggio Emilia inspired learning groups: } \\
\text { Relationships, communication, cognition, and play. Early Childhood Education } \\
\text { Journal, 45(5), 629-639. } \\
\text { * Knauf, H. (2017). Documentation as a tool for participation in German early } \\
\text { childhood education and care. European Early Childhood Education Research } \\
\text { Journal, 25(1), 19-35. } \\
\text { * Macartney, B. \& Morton, M. (2013). Kinds of participation: Teacher and } \\
\text { special education perceptions and practices of 'inclusion' in early childhood } \\
\text { and primary school settings. International Journal of Inclusive Education, 17(8), 776- } \\
\text { 792. } \\
\text { * McAnelly, K. \& Gaffney, M. (2019). Rights, inclusion and citizenship: A } \\
\text { good news story about learning in the early years. International Journal of } \\
\text { Inclusive Education, 23(10), 1081-1094. } \\
\text { * Soncini, I. (2012). The inclusive community. In C. Edwards, L. Gandini, \& } \\
\text { G. E. Forman (Eds.), The hundred languages of children: The Reggio Emilia experience } \\
\text { in transformation (3rd ed., pp. 187-212). Oxford, England: Praeger. } \\
\text { * Thompson, N. (2006). «She is our little sister» reflections about inclusion. } \\
\text { Innovations in Early Education: the International Reggio Exchange, 13(1), 12-20. } \\
\text { * Vakil, S., Freeman, R., Swim, T.J. (2003). The Reggio Emilia approach and } \\
\text { inclusive early childhood programs. Early Childhood Education Journal, 30(3), 187. } \\
\text { * Villines, M. (2011). Early childhood inclusion: Teacher perception of the } \\
\text { supports needed to fully include children with special needs. Yayimlanmamis } \\
\text { Yüksek Lisans Tezi, Portland State Üniversitesi, Portland. }\end{array}$ \\
\hline
\end{tabular}

In order to ensure credibility in this research, the researcher makes use of the "rich description," "data diversification," "negative cases," and "explanation of the researcher's prejudices" methods among the credibility methods determined by Creswell and Miller (2000). Moreover, ethical issues are taken into consideration.

\section{Results}

Table 2 presents which of the six main principles (child image, teacher's role, project, role of the environment, documentation, relationships) inclusive education studies in the synthesized data fit. 
Table 2. The theme and the sub-themes found in the data

THEME: Inclusive education in Reggio Emilia and Reggio Emilia-inspired preschools

The Data

\begin{tabular}{|c|c|c|c|c|c|c|c|c|c|c|c|c|}
\hline Sub-themes & 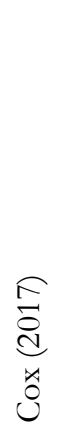 & 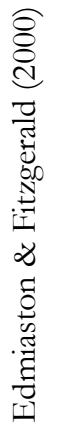 & 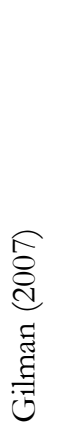 & 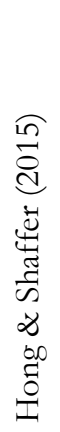 & 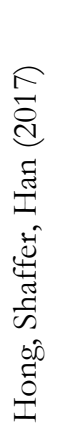 & 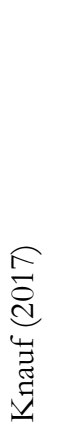 & 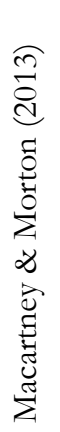 & 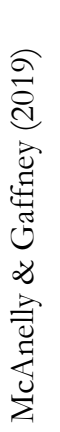 & 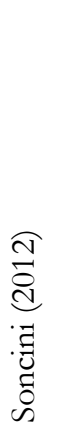 & 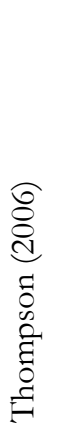 & 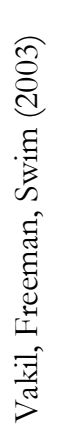 & $\begin{array}{l}\stackrel{\overbrace{}}{\vec{\Xi}} \\
\stackrel{\Xi}{\mathscr{J}} \\
\stackrel{\mathscr{J}}{\Xi}\end{array}$ \\
\hline Child image & $\checkmark$ & $\checkmark$ & $\checkmark$ & & & & & $\checkmark$ & $\checkmark$ & $\checkmark$ & & \\
\hline Teacher's role & $\checkmark$ & $\checkmark$ & $\checkmark$ & $\checkmark$ & & & & & $\checkmark$ & $\checkmark$ & & \\
\hline Project & & $\checkmark$ & $\checkmark$ & & $\checkmark$ & & & & $\checkmark$ & & $\checkmark$ & $\checkmark$ \\
\hline Environment's role & $\checkmark$ & $\checkmark$ & & & & & & $\checkmark$ & $\checkmark$ & $\checkmark$ & & \\
\hline Documentation & $\checkmark$ & $\checkmark$ & & & & $\checkmark$ & & & $\checkmark$ & & & \\
\hline Relationships & $\checkmark$ & $\checkmark$ & $\checkmark$ & $\checkmark$ & $\checkmark$ & $\checkmark$ & $\checkmark$ & $\checkmark$ & $\checkmark$ & $\checkmark$ & & $\checkmark$ \\
\hline
\end{tabular}

In terms of the second question of the current research, it is found that the data on inclusive education deriven from Reggio Emilia-inspired preschools do not fully consider Reggio Emilia principles but only partially.

\section{Conclusion and Discussion}

When the studies on children with special rights in preschools are examined, the following sequence emerges from the most heavily emphasized principles to the least emphasized ones:

1. Relationships

2. Child Image

3. Teacher's Role

4. Project

5. Environment's Role

6. Documentation

It is found in the data that relationships principle is the most emphasized one whereas documentation principle is the least emphasized one. In fact, in Reggio Emilia schools, each principle needs to be equally paid attention. Otherwise, when one part of the Reggio Emilia system does not work, the whole system might collapse because each of the principles is related to each other. Below, suggestions are developed based on the data that comes from research studies for whoever wants to adopt Reggio Emilia principles and conduct inclusive education in their Reggio Emilia-inspired preschools. 
Things to do before starting to school:

Pedagogista (education specialist), who is in charge of establishing the link between the school and healthcare services, should find out what motivates the child and identify the interests of the child in cooperation with the family.

The teacher should accomplish careful observation and documentation to find out the interests of the child and motivation sources.

The teacher should make home visits to observe how the child uses the environment and what strategies their parents use.

The teacher should support varying levels of development and differences among children by the group learning approach.

The teacher might not hold special education, but before the child starts the school, the teacher should try to learn as much as possible about the child and his/her needs. For this, the teacher, parents, pediatrician and pedagogista should cooperate.

In the next step, the teacher should prepare the children in the class for their new friend and together they should plan how to meet him/her.

What to do after starting the school:

How the disability affects the child needs to be examined without prejudice and the whole child principle needs to be taken into consideration while evaluating the child with special needs.

Only one or two children with special rights should be assigned to each class. One extra teacher should be given to that class. However, this teacher takes care of all children.

If two children with special rights are to be placed in a class of 20 , it should be ensured that they have different needs.

Unless there is a severe disability, no special treatment should be done in the classroom, but like other children, the child with special rights needs to be in the teacher's special radar.

Through documentation, the teacher should prepare the education program according to the interests and needs of each child. Documentation including continuous observation, interpretation and evaluation should be done to determine what the child is interested in.

Often educational programs label children and group them for easier learning. However, in Reggio Emilia schools, every child is seen as creative and resourceful. Each child constructs new information in accordance with his/her past experiences, his/her current understanding and the provocation done by the teacher. The teacher should remember that how far a child will progress is specific to that child. 


\section{GİRİŞ}

Reggio Emilia yaklaşımı; çağdaş, kaliteli ve çocuk haklarını üst düzeyde gözeten bir erken çocukluk eğitimi anlayışıdır. İlk Reggio Emilia anaokulu, İtalya’nın Reggio Emilia kasabasında doğmuştur ve 1991 yllında Newsweek gazetesi tarafından "Dünyanın en iyi erken çocukluk kurumu” seçilmiştir (Thornton ve Brunton, 2015). Tüm dünyada hızla tanınan ve yaygınlaşan Reggio Emilia yaklaşımı, erken çocukluk eğitiminde "altın standart" olarak ifade edilmektedir (New, 2007; Thornton ve Brunton, 2010). Loris Malaguzzi önderliğinde II. Dünya Savaşı'nın hemen ardından zorluklar içinde temelleri atılan Reggio Emilia okulları, çocuklara verdikleri değerle, oluşturdukları kaliteli ve sosyalyapılandırmacı eğitim ortamıyla, sanat ve bilimin içiçe geçtiği proje çalışmalarıyla, bireysel farklılıkları gözeten değerlendirme çalışmalarıyla ve çocukların merakları doğrultusunda gelişen çağdaş eğitim uygulamalarıyla ön plana çıkmıştır (Dahlberg, 2000; Edwards, 1998; Emilia Romagna, 1993; Filippini, 1998; Gandini, Hill, Cadwell ve Schwall, 2005; Malaguzzi, 1998; Rinaldi, 2006).

Reggio Emilia yaklaşımının kuramsal çerçevesini oluşturan altı adet prensip vardır. Reggio Emilia prensiplerinin ilki çocuk imajıdır. Reggio Emilia okullarında bütün çocuklar güçlü, meraklı, ilgileri olan, güzel, etkin ve potansiyel sahibi bir birey olarak kabul edilir (Malaguzzi, 1994). Reggio Emilia prensiplerinin ikincisi öğretmen rolüdür. Öğretmenin rol yelpazesi geniştir. Gözlemci, dinleyici, öğrenci, bakıcı, arkadaş ve provokatör gibi rolleri vardır (Rinaldi, 1993). Diğer eğitimcilerle ve paydaşlarla işbirliği içinde çalışır. Reggio Emilia prensiplerinin üçüncüsü proje çalışmalarıdır. Çocuklar ve öğretmen tarafindan geliştirilen uzun süreli, derinlemesine araştırmalar içeren proje çalışmaları yapılır (Rinaldi, 1998). Reggio Emilia prensiplerinin dördüncüsü çevrenin rolüdür. Reggio Emilia okullarında iyi planlanmış bir çevre ve proje çalışmalarını destekleyen, çocukların ilgi ve ihtiyaçlarına hitap eden "akıl malzemeleri” mevcuttur. Çevre, çocukların merakını ve öğrenmesini körüklediği için 3. öğretmen olarak adlandırılır (Gandini, 1998). Reggio Emilia prensiplerinin beşincisi dokümantasyondur. Sonuç değil süreç odaklı bir çalışma olan dokümantasyon sayesinde çocukların çalışmaları ve ilerlemesi pedagojik amaçlı olarak devamlı takip edilir (Gandini, 2004).

Reggio Emilia prensiplerinin sonuncusu ilişkilerdir. Bireyselci anlayışlardan farklı olarak sosyokültürel anlayışa dayalı olan Reggio Emilia yaklaşımı; toplum, öğretmenler, aileler ve çocuklar arasındaki bağı çok önemser ve eğitimde bu bağı kullanır (Rinaldi, 1998). Bu yaklaşımı anlatırken, Malaguzzi (1993), modern yaşamın getirdiği yalnızlık, kendini farklı hissetme, ayrı kalma ve şiddetin zararlarına değinir ve "Bizim amacımız, öğretmenlerin, çocukların ve ailelerin kendilerini ait hissettikleri canlı bir okul ortamı yaratmaktır” der (s. 9). Bu amaç, Reggio Emilia yaklaşımının altı prensibinden biri olan "İlişkiler” prensibini yansıtmaktadır. 
Türkiye'de son yıllarda yaygınlaşmaya başlayan, Reggio Emilia yaklaşımına dair merak edilen pek çok konu bulunmaktadır. Okul öncesi kurumlarının, eğitim felsefesi olarak esinlendiği sosyalyapılandırmacı nitelikte olan bu yaklaşım, batılı bakış açılarından farklı uygulamalarıyla gündeme gelmiştir. Bilim, sanat ve teknolojinin birlikte yoğrulduğu bu okullarda, çocuklara nasıl eğitim verildiği, çevrenin nasıl “3. öğretmen” olarak tasarlandığı ve öğretmenin görev yelpazesi gibi pek çok konu merak edilmektedir. Bu araştırmanın da konusu olan ve çok merak edilen bir başka nokta, bu okullarda engelli veya özel gereksinimli olarak tanımlanan çocuklara nasıl bir eğitim verildiğidir. Zira İtalya, 1970’lerin ortalarından itibaren başlattığı çalışmalarla, Avrupa'da en iyi kaynaştırma yapan ülkelerden biri olmuştur (editör notu, Soncini, 2012). Ancak Türkiye'de Reggio Emilia okullarında kaynaştırma konusunda hiç yayın bulunmamaktadır.

Bu araştırma, Reggio Emilia okullarında kaynaştırma konusunu incelemesi açısından Türkiye'de ilk olması nedeniyle öncü niteliğinde bir çalışmadır. Reggio Emilia çalışmalarının Türkiye'de yeni yaygınlaşmaya başladığ1 ve Reggio Emilia okullarındaki kaynaştırma eğitimine ilişkin Türkçe kaynak bulunmadığ1 göz önünde bulundurulduğunda, bu çalışmanın bir farklılık oluşturacağ1 ve dolayısıyla okul öncesi eğitimi alanına ve özel eğitim alanına katkı sağlayacağı düşünülmektedir.

\section{TEORİK VE KAVRAMSAL YAPI}

$\mathrm{Bu}$ araştırmanın konusu Reggio Emilia yaklaşımını benimseyen okul öncesi kurumlarında kaynaştırma eğitiminin nasıl gerçekleştirildiğidir. Sadece İtalya’da Reggio Emilia kasabasında bulunan okullar "Reggio Emilia okulu" olarak adlandırılmaktadır. Bunun dışındakiler "Reggio Emilia-ilhamlı okul" olarak adlandırılmaktadır. Dolayısıyla, teorik ve kavramsal yapı bölümünde sadece bu yaklaşımının ana kaynaklarına yer verilmiştir. Öte yandan, çalışmanın verilerini oluşturan kaynaklar için hem Reggio Emilia okullarındaki kaynaştırma uygulamalarını hem de Reggio Emiliailhamlı okullardaki kaynaştırma uygulamalarını ortaya koyan kaynaklar kullanılmıştır.

\section{Reggio Emilia Okullarında Kaynaştırma}

Gandini ve Kaminsky (2006), Reggio Emilia belediyesinde uzun ylllar özel gereksinimleri olan çocuklarla çalışan Ivana Soncini ile yaptıkları röportajda, 1970’lerin başında İtalya'da ilk olarak kaynaştırma uygulamaları yapan okulların Reggio Emilia anaokulları olduğunu ve 1977'de ise, kaynaştırma eğitiminin kanunla zorunlu hale geldiğini belirtmiştir. Bu röportajda Soncini şunları söylemiştir:

Biz bu çocukları ciddiyetle karşıladık ve bize neler öğretebileceklerini anlamaya çalıştık. Loris Malaguzzi, daha geniş bir pedagojik yaklaşım oluşturabilmemiz ve bütün çocuklara ilişkin vizyonumuzu geliştirebilmemiz için, 
bu çocukları diğer çocuklarla birlikte tutmamızın bize fikir vereceğine inanırdı. Malaguzzi farklılıkların, yeni düşünceleri ve yeni fikirleri tetikleyeceğine inanırdı çünkü bütün çocuklardaki farklılıklarla ilgilenirken homojen metotların kullanılamayacağını düşünürdü (s.1).

Bu kanuna göre 20 kişilik bir sınıfa en fazla iki tane özel gereksimleri olan çocuk verilebilir; iki çocuk birbiriyleriyle karşılaştırılmasın diye, teşhislerinin aynı olmamasına dikkat edilir; bu sınıfa bir tane fazladan destek öğretmeni atanır; 3-5 yaş arası özel gereksinimli çocukların okula devamı zorunludur; pedagogistalar, yönetimsel işlerden ve psikolojik danışmanlıktan sorumlu psikologlardır ve Yerel Sağlık Merkezi ile okul arasında iletissimi kurar ve merkez tarafindan teşhis konulmuş çocuklarla ilgili öğretmenlere bilgi verirler; merkezi eğitim sistemi olmayan Reggio Emilia kasabasında, tüm halk bu çocukların eğitimi hakkında söz sahibidir; bireyselleştirilmiş eğitim, grupça öğrenme ortamında gerçekleşir (Palsha, 2002).

Reggio Emilia yaklaşımının kavramsal alt yapısı üç temel öğeden oluşmaktadır:

1) Ebeveynlerin ve eğitimcilerin İtalya'da sıradışı okul kurma hayalleri,

2) Çocukların deneyimleri,

3) Gelişim/öğrenme teorileri —özellikle Vygotsky'nın sosyal-yapılandırmacı anlayışı ve Piaget’in bilişsel gelişim kuramı (Malaguzzi, 1998).

İkinci ve üçüncü öğeler teori ve pratiğin dengeli bir şekilde eğitime yansıtıllması üzerine durmaktadır. Örneğin, Reggio Emilia öğretmeni plan yaparken hem çocukların merak ettiği konuları dikkate alır hem de sosyo-kültürel kurama uygun olarak eğitim planını grup çalışmaları gerçekleşecek şekilde tasarlar (Rinaldi, 1993; Rinaldi, 1998). Ayrıca, sosyal-yapılandırmacı anlayış gereği, gerçek hak sahipliği, gerçek demokrasi ve gerçek vatandaşlık için, dışarıdan kontrolör olarak değil içeriden ortak kurucular olarak vatandaşların katılımı desteklenir. Bu yüzden Reggio Emilia okullarında öğretmenler, ebevenyler ve çocukların, yani herkesin katılımcı olması sağlanır ve eğitim deneyimleri hepbirlikte inşa edilir (Cagliari, Soncini, Nicolosi, 2019).

Birinci öğe ile ilgili olarak ise, Reggio Emilia yaklaşımının kurucusu, eğitimci Loris Malaguzzi Reggio Emilia okulları için kurdukları hayali, yani neye değer verdiklerini şöyle anlatmaktadır:

Bizim varış noktamız, çocukların, öğretmenlerin ve ailelerin kendilerini iyi hissettikleri, sevimli, çalışkan, üretici, icatçı, yaratıcı, yaşanabilir, belgelenebilir, iletişim kurulabilir, araştırma ve öğrenme yeri olan, yeniden ve dönüşümlü düşünmenin (reflection) yapıldığı bir okuldur (Malaguzzi, t/y). 
Bu okulda, özel gereksinimli çocuklar da dahil olmak üzere, tüm çocuklara yer vardır. Çünkü bütün çocuların okula gitme, iyi öğretmenlere sahip olma, iyi bir binada eğitim alma, doğru zamanda iyi etkinlikler yapma hakları vardır (Malaguzzi, 1994). Kısacası, eğitim almak her çocuğun hakkıdır. Özel gereksinimli çocukların da tipik gelişim gösteren çocuklarla aynı sınıflarda eğitim alma hakkı vardır. Hatta, kaynaştırma eğitimi olarak adlandırılan bu sistemde, özel gereksinimli çocukların tipik gelişim gösteren çocuklarla aynı sınıflarda eğitim almasının, toplumun gerçeğini yansıtması açısından daha doğal bir çevre oluşturduğu gibi yararları olduğu bilinmektedir (Sandall ve Ostrosky, 2000; Shepherd ve Eaton, 1997). Dolayısıyla, öğretmenler, Reggio Emilia anlayışına ve hayal ettikleri okulun mahiyetine uygun olarak özel gereksinimli çocukların eğitimini tasarlamakta, özel gereksinimli çocukların tipik gelişim gösteren akranlarıyla birlikte aynı sınıflarda eğitim alması sağlanmaktadır (Smith, 1998; Soncini, 2012). Kaynaştırma eğitiminin gereği olarak özel gereksinimleri olan çocukların hem fiziksel olarak akranlarıyla yan yana olması hem de onlara sunulan olanaklara erişimlerinin olması sağlanmaktadır (Nurse, 2001).

Palestis (1994) Reggio Emilia okullarındaki gözlemlerini aktarırken, orada "Bütün çocuklar öğrenebilir” mantığının hâkim olduğunu ve öğretmenlerin çocukların zayıflıklarına değil güçlü olduğu yönlerine odaklandığını belirtir. Reggio Emilia okullarında ciddi bir not verme (başarılı, başarısız gibi) ve etiketleme olmadığından söz eder. Çünkü amaç, bütün çocukların güçlü yönlerini gün ışığına çıkartmak ve güçlendirilmesi gereken yönleri üzerinde çalışmalar yapmaktır. Dolayısıyla, çocuklara olumsuz etiketler yapıştırmak yerine, onların farklılıklarını toplumda var olan birçok farklılıktan biri olarak kabul ederler (Malaguzzi, 1994). Reggio Emilia öğretmenleri, özel gereksinimi olan çocukları gereksinimleri olan bireylerden ziyade "özel hakları olan bireyler" olarak adlandırırlar çünkü onların daha fazla haklara sahip olmaları gerektiğini savunurlar (Rinaldi, 1998; Soncini, 2012). Bu nedenle, bu makalede “özel gereksinimli çocuklar," “özel hakları olan çocuklar” terimleri birbirinin yerine kullanılmıştır.

Bailey ve Wolery (1992) özel gereksinimli çocuklara yönelik iyi bir kaynaştırma eğitiminin üç özelliği olduğunu vurgular:

1) Öğretmenin devamlı gözlem yapabilmesine olanak sağlayan bir ortam,

2) Çocukların ve yetişkinlerin rahat ve güvende hissettiği işlevsel bir ortam,

3) Özgürlüğün desteklendiği bir ortam. 
Reggio Emilia prensipleri bu kriterleri çok başarılı bir şekilde karşılamaktadır. Örneğin, Bu kriterlere paralel olarak, Reggio Emilia okullarında öğretmenler, dokümantasyon yöntemi sayesinde devamlı çocukları gözlemler, Reggioca dinleme yani dokümantasyon ve değerlendirme yaparlar (Gandini, 2004; Rinaldi, 1998; Rinaldi, 2004). Reggio felsefesinde varolan “ilişkiler" ve "çevre" prensiplerine uygun olarak, hem yetişkinler hem de çocuklar için rahat, güvenli, öğretici, yapılandırmacı, sosyal ve toplumun mikro-organizması olan bir ortam yaratırlar (Ceppi ve Zini, 1998). Son olarak yetişkinlerin rehberliğinde ve 3. öğretmen olan çevre sayesinde, çocuğun gelişmesi ve eğitimi için maksimum özgürlüğün desteklendiği bir çevre oluştururlar (Gandini, 2002).

Çocukların sosyal, kültürel ve tarihsel geçmişlerine vurgu yapan Vytgotsky'nin sosyalyapılandırmacı anlayışına dayalı olan Reggio Emilia yaklaşımı (Malaguzzi, 1998; Rinaldi, 1993) Türkiye'de hızla yayılmaktadır. Okul öncesi eğitime farklı bir bakış açısı getirdiği görülen bu yaklaşımın daha iyi tanınması açısından yeterli sayıda Türkçe kaynak bulunmamaktadır. Örneğin, Reggio Emilia yaklaşımını genel olarak anlatan sınırlı sayıda kitap bölümü ve makalenin yanısıra sadece iki adet kitap bulunmaktadır -“Reggio Emilia yöntemiyle barika çocuk yetiştirmek”" (Cadwell, 2011) ve “Okul öncesi eğitiminde çağdaş yaklaşımlar: Reggio Emilia ve Proje Yaklaşımı” (İnan, 2012). Öte yandan, Reggio Emilia kaynaştırma eğitimine dair Türkçe kaynağa rastlanmamıştır. Hem Reggio Emilia okullarında kaynaştırmaya ilişkin ilk Türkçe yayın olması hem de sosyal-yapılandırmacı anlayışa dayalı olması nedeniyle bu araştırmanın eğitim alanına katkı sağlayacağı düşünülmektedir. Zira bireysel gelişim kuramcılarının aksine, Vygotsky, Rogoff ve diğer sosyal-yapılandırmacı teorisyenleri temel alan kaynaştırma eğitimi üzerine kaynaklar da çok az sayıdadır (Mallory ve New, 1994). Dolayısıyla, bu araştırmanın Türkiye'de okul öncesi eğitimiyle bütünleşen Reggio Emilia yaklaşımı hakkında bilgi sahibi olmak isteyen ailelere ve eğitimcilere katk1 sağlayarak, özel hakları olan çocuklar için daha etkin öğrenme ortamlarının oluşturulmasına yardımcı olması beklenmektedir.

\section{Çalışmanın Amacı}

Bu meta-etnografik araştırmanın amacı, tipik gelişim gösteren çocukların devam ettiği Reggio Emilia sınıflarında, özel gereksinimli çocukların nasıl bir kaynaştırma eğitimine tabi tutulduğunu ortaya koyan çalışmaları incelemek ve sentezlemektir. Bu meta-sentez sonucunda eğitimcilere 1şık tutabilecek açıklamalar ve öneriler geliştirilmiştir. Türkiye'de benzer bir çalışma bulunmadığından, Reggio Emilia okullarında sunulan kaynaştırma eğitimine ilişkin bilgi sahibi olmak ve uygulamalar yapabilmek açısından, bu araştırmanın eğitimcilere ve karar-vericilere yardımcı olacağı düşünülmektedir. Bu araştırmada Noblit ve Hare'nin (1988) yedi basamaklı meta-etnografi metodunun kullanılmasının sebebi ise, sosyal-yapılandırmacı Reggio Emilia felsefesinin doğasına 
uygun olarak, araştırmaların çoğunlukla nitel ve yorumcul paradigmaya uygun olarak gerçekleşiyor olmasıdır. Dolayısıyla, bu araştırmada Reggio Emilia okullarında uygulanan özel eğitim, metaetnografik araştırma metodu kullanılarak ortaya çıkarılmıştır ve yeniden sentezlenmiştir. $\mathrm{Bu}$ çalışmanın genel amacın uygun olarak aşağıdaki sorulara cevap aranmıştır:

Araştırma Sorusu 1-Reggio Emilia yaklaşımın esas alan kaynaştırma eğitimi araştırmaları, altı ana prensipten (çocuk imaji, ögretmen rolü, proje, çevrenin rolü, dokümantasyon, iliskiler) hangisine/ hangilerine uyum săglamıstır?

Araştırma Sorusu 2- Reggio Emilia yaklaşımm esas alan kaynaştırma eğitimi araştırmalar Reggio Emilia prensiplerine nasıl uyum sağlamıstır?

\section{YÖNTEM}

Bu bölümde, yöntem ve izlenen süreç hakkında bilgiler verilmiştir.

\section{Araştırma Deseni}

$\mathrm{Bu}$ çalışmada, Reggio Emilia yaklaşımının sosyal-yapılandırmacı yapısına uygun olarak, nitel araştırma deseninden yararlanılmıştır. Bu araştırmada, nitel araştırma yöntem ve tekniklerinden, meta-etnografi metodu seçilmiştir, çünkü meta-etnografi metodu nitel araştırmaları yorumlamaya ve tümevarım yoluyla kümülatif sentez yapmaya olanak sağlamaktadır (Campbell et al., 2011; Ellis, 2009; Elsevier, 2020; Hughes ve Noblit, 2017; Noblit ve Hare, 1988; Noyes, 2006). Birçok araştırma metodunda olduğu gibi farklı uygulamaların olduğu meta-etnografi metodunu Elsevier (2020) şöyle tanımlamaktadır:

\footnotetext{
Meta-etnografi, araştırmaya dahil edilen çalışmaların nitel araştırma bulgularını sentezlemek için kullanılan bir yöntemdir. Bulguların, toplu ve tamamen nicel bir özetinden ziyade, yorumlayıcı bir sentezini oluşturur ve birden çok kaynağın bulgularının entegrasyonuna izin verdiği için farklı alanyazınları sentezlemek için eşsiz bir şekilde çok uygun bir yöntemdir. [Meta-etnografi] Tümevarım ve yorumlamayı içerir ve birinci dereceden analiz yöntemlerine benzer bir yaklaşım izler (sentezlenen çalışmalarda kullanılan nitel veri analizi). Metaetnografi yoluyla, farklı çalışmaların kavramları çıkarılarak, ikinci dereceden bir kavram oluşturulur. Yorumlayıcı bir metottur ve dolayısıyla kesinlikle karşılaştırılabilir çalışmaları sentezlemekle sınırlı değildir. Nicel çalışmalar, nitel çalışmalar, gri literatür ve profesyonel uzmanlık gibi çeşitli kaynaklardaki bilgileri sentezlemek için kullanılabilir. Başka bir deyişle, meta-etnografi, etnografik veya genel olarak nitel çalışmaları genelleştirir. (s.17)
}

Bu metot sayesinde Reggio Emilia okullarında gerçekleşen kaynaştırma eğitimi uygulamalarına dair nitel çalışmalar sentezlenmiş ve merak edilen konu, bağlamından koparılmadan genel bir çerçeve 
içinde sunulmuştur. Bu sayede birincil kavramsal tema yani "Reggio Emilia okullarında ve Reggio Emilia-ilhamlı okullarda kaynaştırma eğitimi” yeniden yorumlanmış ve varolan çelişkili kavramlarla birlikte sentezlenmiştir. Bu tema bağlamında, araştırma sorularına uygun olarak, Reggio Emilia yaklaşımını esas alan kaynaştırma eğitimi araştırmalarının altı ana prensipten (çocuk imajı, öğretmen rolü, proje, çevrenin rolü, dokümantasyon, ilişkiler) hangisine/hangilerine uyum sağladığı ve nasıl uyum sağladığı sentezlenmiştir.

\section{Araştırmada İzlenilen Süreç: Veri Toplama ve Veri Analizi}

Bu araştırmada kullanılan Noblit ve Hare'nin (1988) meta-etnografi metodu, yedi basamaktan oluşmaktadır. Bu araştırmada, Gürgür ve Yazçayır'ın da (2019) yorumlamasıyla, Noblit ve Hare'nin belirttiği 7 basamağı bu çalışmaya uyarlanmış ve "Reggio Emilia okullarında ve Reggio Emiliailhamlı okullarda kaynaştırma eğitimi” temasına uygun olarak yeniden yapılandırılmıştır (bakınız Şekil 1). 


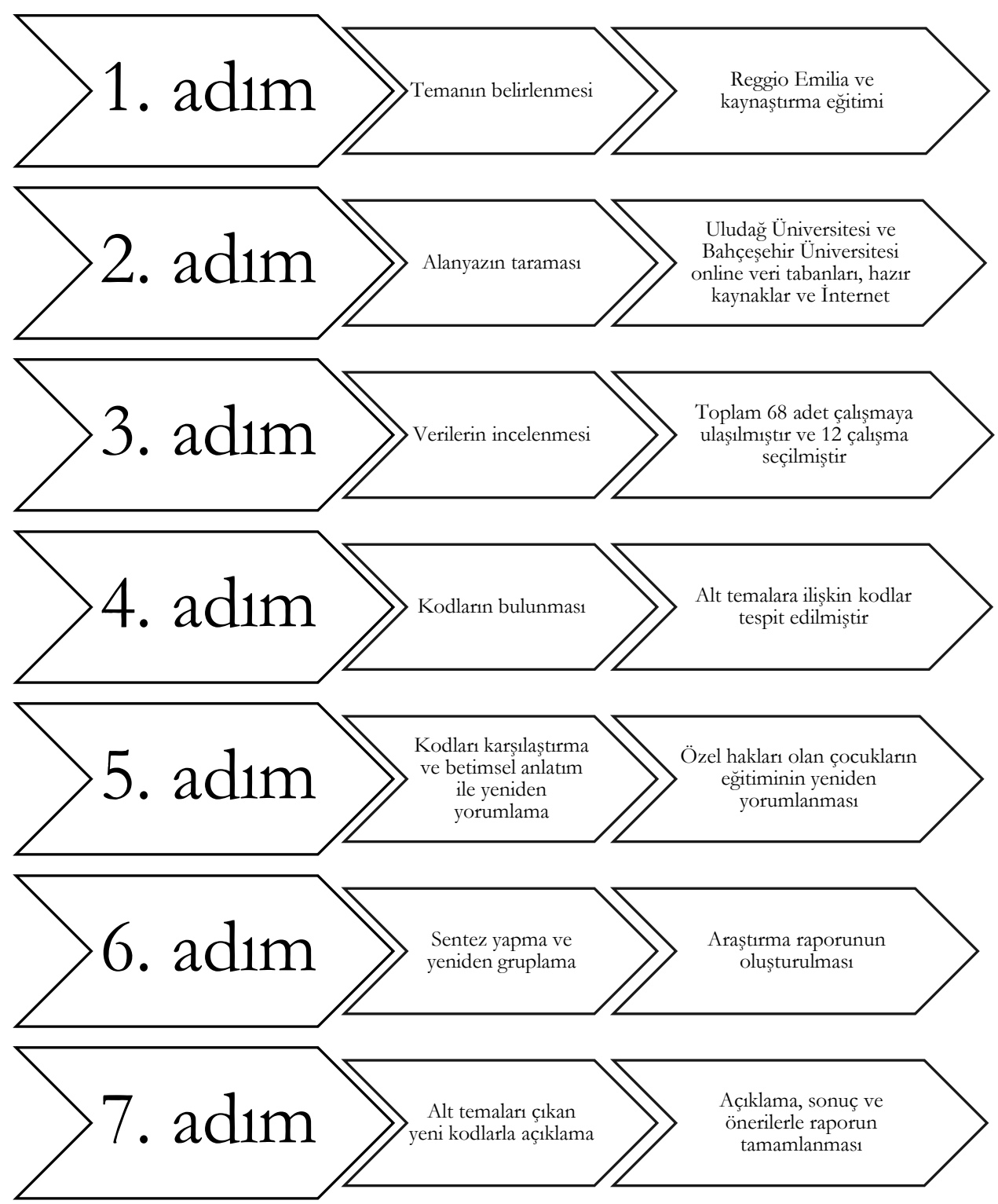

Şekil 1. Kaynaştırma eğitimi çalışsmalarının sentezlenmesinde izlenilen meta-etnografi adımları

Birinci adımda, genel bir alanyazın taraması yapılmış, öncelikle odaklanılacak konu yani tema "Reggio Emilia Okullarında ve Reggio Emilia-İlhamlı Okullarda Kaynaştırma Eğitimi” olarak belirlenmiş ve olası anahtar kelimeler düşünülmüştür. İkinci ve üçüncü adımda, Bursa Uludağ Üniversitesi ve Bahçeşehir Üniversitesi kütüphanesinin üye olduğu çevrim içi kataloglar taranarak, halihazırda varolan kaynaklar kullanılarak ve İnternet tarama motorları üzerinden araştırma yapılarak ilgili konudaki çalışmalara ulaşılmıştır. Geniş bir tarama yapılmıştır ve ilgili konuda çok kısıtlı kaynakların olduğu tespit edilmiştir ve uygun olanlar seçilmiştir (Tablo 1). Örneğin, ProQuest Dissertations ve Theses Global veritabanında ilgili konuya yakın yalnızca bir adet teze ulaşılmıştır: Portland State Üniversitesi'nde, 2011 yilında, Meredith Villines tarafindan yazılan "Early Childhood 
Inclusion: Teacher Perception of the Supports Needed to Fully Include Children with Special Needs" isimli tez. Bu sebeple, meta-etnografi metodunun doğasına da uygun olarak temayla ilintili tüm nitel çalışmalar toplanmıştır. Bu süreç, tüm araştırma boyunca ihtiyaç duyuldukça tekrar edilmiştir. Toplanan kaynaklar okunmuş, bu araştırmanın verisini oluşturan kaynaklar tespit edilmiş ve çok ilgisiz olanlar ayıklanmıştır (Tablo 1). Ancak, ilgili konuda nitel çalışmaların çok kısıtlı olmasından dolayı, fazladan bir kısıtlamaya (örn., konunun daraltılması için yeni anahtar kelime eklemek) gitmemeye özen gösterilmiştir.

Tablo 1. Bu araștırmada kullanılan verilerin tam künyeleri ve bunlara ulaşmada kullanılan araçlar ve anahtar kelimeler

\begin{tabular}{|c|c|c|}
\hline banlar1 & $\begin{array}{l}\text { Anahtar } \\
\text { kelimeler }\end{array}$ & ş Veriler \\
\hline $\begin{array}{l}\text { *Bursa Uludağ } \\
\text { Üniversitesi ve } \\
\text { Bahçeşehir } \\
\text { Üniversitesi } \\
\text { kütüphanesinin } \\
\text { üye olduğu } \\
\text { online } \\
\text { kataloglarda } \\
\text { Toplu Tarama } \\
\text { (örn., } \\
\text { Ebscohost } \\
\text { üzerinden } \\
\text { e-tez, e-kitap, e- } \\
\text { dergi, Türkçe e- } \\
\text { dergi) } \\
\text { *Araştırmacının } \\
\text { elindeki hazır } \\
\text { kaynaklar } \\
\text { *İnternet } \\
\text { tarama } \\
\text { motorları }\end{array}$ & $\begin{array}{l}\text { *Reggio Emilia } \\
\text { *Inclusion } \\
* \text { Special needs } \\
\text { *Special rights } \\
\text { *Special } \\
\text { education } \\
* \text { Disability }\end{array}$ & $\begin{array}{l}\text { *Cox, L. (2017). Children with special rights in Reggio Emilia - A story of the } \\
\text { possible. International Educator, 31(4), 10-33. } \\
\text { *Edmiaston, R. \& Fitzgerald, L.M. (2000). How Reggio Emilia encourages } \\
\text { inclusion. Educational Leadership 58(1), 66. } \\
\text { *Gilman, S. (2007). Including the child with special needs: Learning from } \\
\text { Reggio Emilia. Theory into Practice, 46(1), 23-31. } \\
\text { *Hong, S.B. \& Shaffer, L.S. (2015). Inter-professional collaboration: Early } \\
\text { childhood educators and medical therapist working within a collaboration. } \\
\text { Journal of Education and Training Studies, 3(1), 135-145. } \\
\text { *Hong, S.B., Shaffer, L., Han, J. (2017). Reggio Emilia inspired learning groups: } \\
\text { Relationships, communication, cognition, and play. Early Childhood Education } \\
\text { Journal, 45(5), 629-639. } \\
\text { * Knauf, H. (2017). Documentation as a tool for participation in German early } \\
\text { childhood education and care. European Early Childhood Education Research } \\
\text { Journal, 25(1), 19-35. } \\
\text { * Macartney, B. \& Morton, M. (2013). Kinds of participation: Teacher and } \\
\text { special education perceptions and practices of 'inclusion' in early childhood } \\
\text { and primary school settings. International Journal of Inclusive Education, 17(8), 776- } \\
\text { 792. } \\
\text { * McAnelly, K. \& Gaffney, M. (2019). Rights, inclusion and citizenship: A } \\
\text { good news story about learning in the early years. International Journal of } \\
\text { Inclusive Education, 23(10), 1081-1094. } \\
\text { * Soncini, I. (2012). The inclusive community. In C. Edwards, L. Gandini, \& } \\
\text { G. E. Forman (Eds.), The hundred languages of children: The Reggio Emilia experience } \\
\text { in transformation (3rd ed., pp. 187-212). Oxford, England: Praeger. } \\
\text { * Thompson, N. (2006). «She is our little sisten» reflections about inclusion. } \\
\text { Innovations in Early education; the International Reggio Exchange, 13(1), 12-20. } \\
\text { * Vakil, S., Freeman, R., Swim, T.J. (2003). The Reggio Emilia approach and } \\
\text { inclusive early childhood programs. Early Childhood Education Journal, 30(3), 187. } \\
\text { * Villines, M. (2011). Early childhood inclusion: Teacher perception of the } \\
\text { supports needed to fully include children with special needs. Yayimlanmamiş } \\
\text { Yüksek Lisans Tezi, Portland State Üniversitesi, Portland. }\end{array}$ \\
\hline
\end{tabular}


Tablo 2. Bu araştırmanın verilerinin kullandığı yöntemler ve içerikleri

\begin{tabular}{|c|c|c|}
\hline Veriler & Yöntem & İçerik \\
\hline Cox (2017) & Nitel & $\begin{array}{l}\text { Kaynaştırma eğitimi dâhil olmak üzere Reggio Emilia } \\
\text { okullarındaki pedagojik yaklaşıma dair gözlem notları }\end{array}$ \\
\hline Edmiaston \& Fitzgerald (2000) & Nitel & $\begin{array}{l}\text { Reggio Emilia-ilhamlı okulda Reggio Emilia'nın } \\
\text { kaynaştırmayı nasıl desteklediğine dair gözlem notları }\end{array}$ \\
\hline Gilman (2007) & Nitel & $\begin{array}{l}\text { Reggio Emilia-ilhamlı okulda Reggio Emilia'nın } \\
\text { kaynaştırmayı nasıl desteklediğine dair eylem } \\
\text { araştırması }\end{array}$ \\
\hline Hong \& Shaffer (2015) & Nitel & $\begin{array}{l}\text { Reggio Emilia-ilhamlı okulda öğretmenler ve } \\
\text { terapistlerle yapılan görüşme ile Reggio Emilia'nın } \\
\text { kaynaştırmayı nasıl desteklediğine dair görüşme }\end{array}$ \\
\hline Hong, Shaffer, Han (2017) & $\begin{array}{l}\text { Nitel\&Nicel } \\
\text { (Karma) }\end{array}$ & $\begin{array}{l}\text { Reggio Emilia-ilhamlı okulda Reggio Emilia'nın } \\
\text { kaynaştırmayı nasıl desteklediğine dair gözlem }\end{array}$ \\
\hline Knauf (2017) & Nitel & $\begin{array}{l}\text { Reggio Emilia-ilhamlı } 40 \text { adet okulda Reggio Emilia } \\
\text { dokümantasyon prensibinin kaynaştırma dâhil olmak } \\
\text { üzere eğitimi nasıl desteklendiğine dair sistematik kayıt } \\
\text { için standart bir form, dokümantasyon belgeleri, görsel } \\
\text { veri giriş formu, fotoğrafik durum kaydı, anket ve } \\
\text { görüşme }\end{array}$ \\
\hline Macartney \& Morton (2013) & Nitel & $\begin{array}{l}\text { Reggio Emilia kaynaştırma anlayışının irdelendiği oto- } \\
\text { biyografi ve görüşme }\end{array}$ \\
\hline McAnelly \& Gaffney (2019) & Nitel & $\begin{array}{l}\text { Reggio Emilia-ilhamlı bir okulda Reggio Emilia'nın } \\
\text { kaynaştırmayı nasıl desteklediğine dair gözlem ve } \\
\text { görüşme }\end{array}$ \\
\hline Soncini (2012) & Nitel & $\begin{array}{l}\text { Reggio Emilia kasabasındaki tüm Reggio Emilia } \\
\text { okullarında kaynaştırmayı nasıl gerçekleştirdiklerine } \\
\text { dair kitap bölümü }\end{array}$ \\
\hline Thompson (2006) & Nitel & $\begin{array}{l}\text { Reggio Emilia-ilhamlı bir okulda Reggio Emilia'nın } \\
\text { kaynaştırmayı nasıl desteklediğine dair eylem } \\
\text { araştırması }\end{array}$ \\
\hline Vakil, Freeman, Swim (2003) & Nitel & $\begin{array}{l}\text { Reggio Emilia yaklaşımının kaynaştırma eğitimini nasıl } \\
\text { destekleyeceğine dair analiz }\end{array}$ \\
\hline Villines (2011) & Nitel & $\begin{array}{l}\text { Reggio Emilia-ilhamlı bir okulda Reggio Emilia'nın } \\
\text { kaynaştırmayı nasıl desteklediğine dair görüşme, } \\
\text { eğitimci günlüğü }\end{array}$ \\
\hline
\end{tabular}

Dördüncü adımda, alt temaların (Reggio Emilia'nın altı prensibi) altındaki ilgili kavramların tespit edilmesi için Tablo 3’te görülen örnekteki gibi kod çıkarma işlemi gerçekleştirilmiş ve veri kaynakları arasındaki bağlar tespit edilmiştir. Bunun sonucunda şu üç durum tespit edilmiştir: 
1) Her bir çalışma, Reggio Emilia prensiplerini kısmi veya tam olarak ele almaktadır;

2) Bazı çalışmalar ele aldığı prensibe uygun başarılı uygulama örneği sunmaktadır;

3) Bazı çalışmalar ele aldığı prensibe uymayan uygulamaları/zorlukları dile getirmektedir.

Tablo 3. Kaynak çözümlenmeye üç adet örnek

\begin{tabular}{|c|c|}
\hline Ayıklanmış Veriler & Kodlar \\
\hline $\begin{array}{l}{ }^{*} \text { Cox }(2017) . \text { Children with special } \\
\text { rights in Reggio Emilia - A story of } \\
\text { the possible. }\end{array}$ & $\begin{array}{l}\text { *Çocuk imaj1 } \\
\text { * } \text { Illişkiler } \\
\text { *Atelierista } \\
\text { *Çevre prensibi } \\
\text { *Pedagogista } \\
\text { *Dokümantasyon } \\
\text { *Provokasyon } \\
\text { *Merak duygusu } \\
\text { *Öğretmenin rolü }\end{array}$ \\
\hline $\begin{array}{l}\text { *Edmiaston \& Fitzgerald (2000). } \\
\text { How Reggio Emilia encourages } \\
\text { inclusion. }\end{array}$ & $\begin{array}{l}\text { *Olumsuz veri: Sınıf başına düşen çocuk sayısı } \\
\text { *İliş̧kiler } \\
\text { *Çevre } \\
\text { *Proje } \\
\text { *Dokümantasyon } \\
\text { *İlişkilere prensibine uygun uygulama örneği } \\
\text { *Çevre prensibine uygun uygulama örneği }\end{array}$ \\
\hline $\begin{array}{l}* \text { Gilman }(2007) \text {. Including the child } \\
\text { with special needs: Learning from } \\
\text { Reggio Emilia. }\end{array}$ & $\begin{array}{l}\text { *Çocuk imajı } \\
\text { *Sorular (Felsefenin entegre edilmesi, nasıl kaliteli eğitim } \\
\text { nasıl vermeli, bütün çocukların gelişimi ve öğrenmesinin } \\
\text { desteklendiğinden nasıl emin olunacak?) } \\
\text { *Öğretmen rolü } \\
\text { *İlişkiler } \\
\text { *Olumsuz veri: İlişkiler prensibi } \\
\text { *Proje } \\
\text { *Çocuk imajı uygulama örneği }\end{array}$ \\
\hline
\end{tabular}

Araştırmanın beşinci adımında, kodların yeni bir betimsel anlatı ile yorumlaması yapılmıştır. Altıncı adımda ise, rapor için sentez yapılmış ve tüm veriler yeniden gruplandırılımıștır. Son olarak, yedinci adımda, bu rapor hazırlanmıştır. Bu rapor, bulgular bölümünde detaylı olarak sunulmuştur.

Kısacası etnografik araştırmaların amacı "anlamak” (Spradley, 1980) olduğu için bu meta-etnografik çalışma da, ana tema olan "Reggio Emilia Okullarında ve Reggio Emilia-ilhamlı Okullarda Kaynaştırma Eğitim”in alt temalarını yani Reggio Emilia prensiplerini nasıl hayata geçirdiklerini anlamamıza, parçalar arasındaki ilişkiler ve bu ilişkilerin bütünle olan ilişkisine bakmamızı sağlamıştır (Şekil 2). Zira, Spradley’e göre etnografik analiz, bir kültürü anlamaya çalışırken, “o kültürün parçalarını araştırmak, parçalar arasındaki ilişkileri araştırmak ve bu ilişkilerin bütüne olan katkısını araştırmaktır” (Spradley, 1980, s.116). Bu nedenle meta-etnografik yöntem, bu araştırmanın amacına uygun olarak, Reggio Emilia yaklaşımını temel alan okullardaki kaynaştırma eğitimine ilisskin çalışmaları bir araya getirerek, bir bütün halinde incelememize, sentezlememize ve nihai olarak varolan durumu anlamamıza yardımcı olacak en doğru yöntemdir. 


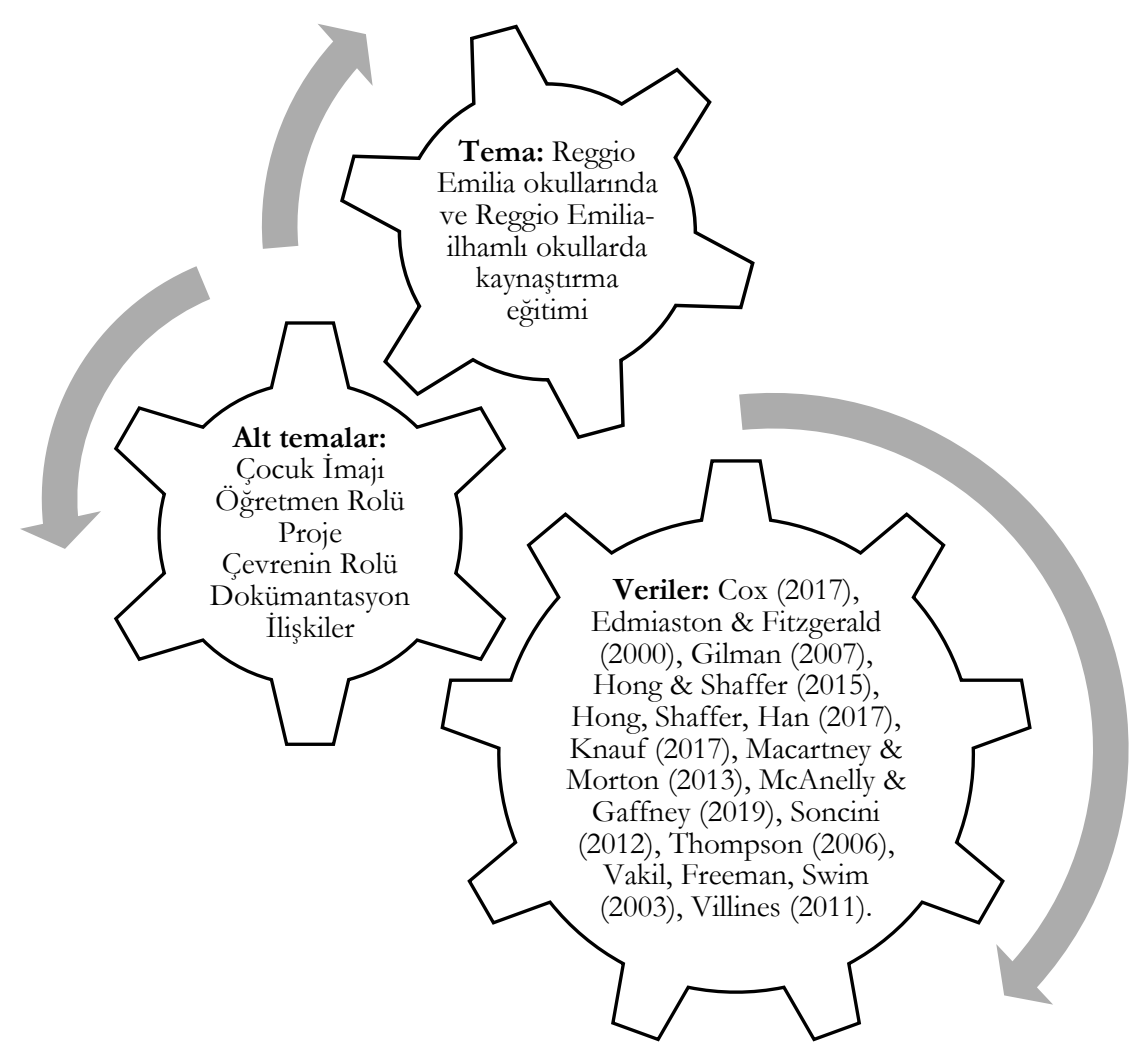

Şekil 2. Tema, alt temalar, veriler

\section{Geçerlik ve Güvenirlik/Sağlamlık (Rigor)}

Bu araştırmada inanırllğın sağlanması için, Creswell ve Miller'ın (2000) önerdiği yöntemlerden “zengin betimleme” (her bir alt tema/prensip altında ç1kan kodlara uygun örnek uygulamalar canlı vaka örnekleriyle desteklenerek paylaşılmış ve böylece zengin betimleme sağlanmaya çalışılmıştır), "veri çeşitlemesi” (hem Reggio Emilia okullarından sorumlu pedagogistanın hem de Reggio Emiliailhamlı eğitimcilerin, araştırmacı-ebeveynlerin ve araştırmacıların seslerinin duyulması sağlanmıştır) ve "olumsuz durum analizi" (yani, kodlara uymayan veya çatışan verilere de yer verilmiştir) gerçekleştirilmiştir. Öte yandan, “araştırmacının ön yargılarını açılklaması” da çalışmanın inanırlığına katkı sağlaması açısından gereklidir. Şöyle ki, araştırmacı, daha önce Amerika Birleşik Devletleri'nde Reggio Emilia-ilhamlı bir laboratuvar anaokulunda, yaklaşık iki yıl süren, kısmi-katılımlı etnografik bir araştırma yürütmüştür ve İtalya'da bulunan Reggio Emilia okullarına ziyaretler gerçekleştirmiştir. Araştırmacının bu tecrübeleri, Reggio Emilia okullarında özel gereksinimli çocuklara sunulan eğitim konusunda olumlu bir bakış açısına sahip olmasına neden olmuştur. Dolayısıyla, bu araştırmaya başlamadan önce, olumsuz durumlardan ziyade daha çok olumlu ve alanda çalışanlara fikir verebilecek verilerin ortaya çıkacağına inanarak araştırmayı başlatımıştır. 
Ancak, Reggio Emilia yaklaşımının tam olarak içselleştirilememiş olması gibi sebeplerden dolayı, az da olsa bazı olumsuz veri örneklerine de rastlamış ve bulgular bölümünde ele almısstır.

\section{Veri Toplama Sürecinde Etik İlkeler}

$\mathrm{Bu}$ araştırma etik ilkeler dikkate alınarak hazırlanmıştır. Alıntılar bilimsel kurallara uygun olarak yapılmıştır. Kullanılan kaynaklar eksiksiz olarak kaynakça bölümünde verilmiştir. Bu araştırmada verilerin kaynağı “doküman” olduğundan -insan veya hayvan olmadığından- dolayı etik kurul alanına girmemektedir. Dolayısıyla, etik kurul izni alınmamıştır. Verilerin kaynağı olan dokümanlar dikkatle analiz edilmiş ve dokümanlardan doğrudan alıntılarla bulgular desteklenmiştir.

\section{BULGULAR}

Bu bölümde bulgulara yer verilmiştir.

\section{Genel Tema ve Alt Temalar}

$\mathrm{Bu}$ araştırmanın birinci sorusu olan Reggio Emilia yaklaşımını esas alan kaynaştırma eğitimi araştırmalarının altı ana prensipten (çocuk imajı, öğretmen rolü, proje, çevrenin rolü, dokümantasyon, ilişkiler) hangisine/hangilerine uyum sağlağına ilişkin bulgular Tablo 4'te sunulmuştur. Tablo 4’te görüldüğü üzere gerçekleştirilen sentezleme üzerine genel tema "Reggio Emilia Okullarında ve Reggio Emilia-ilhamlı Okullarda Kaynaştırma Eğitimi” olarak belirlenmiştir. Her bir veri kaynağının, alt temalardan "1-Çocuk İmaj1; 2- Öğretmen Rolü; 3- Proje; 4- Çevrenin Rolü; 5- Dokümantasyon; 6- İlişkiler" hangisini karşıladığı tik işaretiyle belirtilmiştir. Araştırmanın ikinci sorusuna ilişkin detaylı bilgi bulgular bölümünde sırasıyla verilmiştir. 
Tablo 4. Tema, alt temalar ve alt temaların verilerde (k1smı veya tam olarak) varolma durumu

\section{TEMA: Reggio Emilia ve Reggio Emilia-ilhamlı okullarda kaynaştırma eğitimi}

\section{Veriler}

\begin{tabular}{|c|c|c|c|c|c|c|c|c|c|c|c|c|}
\hline Alt Temalar & 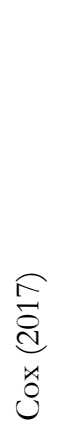 & 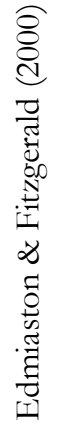 & 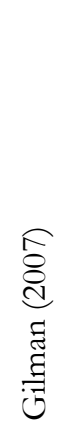 & 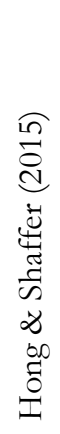 & 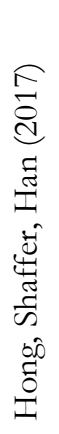 & 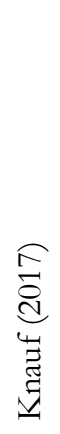 & 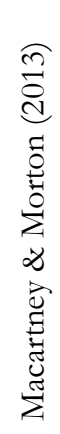 & 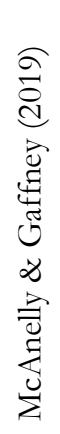 & 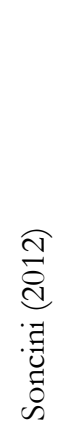 & 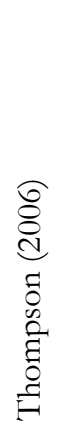 & 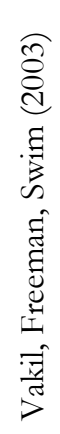 & 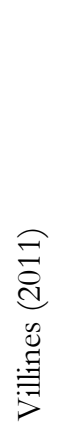 \\
\hline Çocuk İmaj1 & $\checkmark$ & $\checkmark$ & $\checkmark$ & & & & & $\checkmark$ & $\checkmark$ & $\checkmark$ & & \\
\hline Öğretmen Rolü & $\checkmark$ & $\checkmark$ & $\checkmark$ & $\checkmark$ & & & & & $\checkmark$ & $\checkmark$ & & \\
\hline Proje & & $\checkmark$ & $\checkmark$ & & $\checkmark$ & & & & $\checkmark$ & & $\checkmark$ & $\checkmark$ \\
\hline Çevrenin Rolü & $\checkmark$ & $\checkmark$ & & & & & & $\checkmark$ & $\checkmark$ & $\checkmark$ & & \\
\hline Dokümantasyon & $\checkmark$ & $\checkmark$ & & & & $\checkmark$ & & & $\checkmark$ & & & \\
\hline İlişkiler & $\checkmark$ & $\checkmark$ & $\checkmark$ & $\checkmark$ & $\checkmark$ & $\checkmark$ & $\checkmark$ & $\checkmark$ & $\checkmark$ & $\checkmark$ & & $\checkmark$ \\
\hline
\end{tabular}

Her bir alt temanın tek tek hangi veri kaynağında var olduğu tespit edilmiş ve Tablo 4'te sunulmuştur. Ancak, örneğin, Cox (2017) veri kaynağında “çocuk imajının” var olması demek, çocuk imajı prensibinin tam olarak karşılandığı anlamına gelmemektedir. Cox, çocuk imajını, sadece, çocuğun özeline inmek ve farklilıklara değer vermek olarak yorumlamıştır. Öte yandan, Tablo 4’te görüldüğü üzere bazı veri kaynakları, Reggio Emilia presiplerini temsil eden alt temalardan bazılarına uyum sağladığına ilişkin bulguya rastlanmamıştır. Örneğin, Edmiaston ve Fitsgerald'ın çalışmasında tüm prensiplere ilişkin bulgu tespit edilirken, Knaufun çalışmasında sadece dokümantasyon ve ilişkiler prensiplerine ilişkin bulgular tespit edilmiştir. Yani, Edmiaston ve Fitsgerald'ın çalışmasında kaynaştırma eğitimi Reggio Emilia yaklaşımının tüm prensiplerine uygun olarak gerçekleşirken, Knaufun çalışmasında söz konusu olan kaynaştırma eğitimi Reggio Emilia yaklaşımının prensiplerinden sadece dokümantasyon ve ilişkiler prensiplerine uygun olarak gerçekleşmektedir. Öte yandan, Tablo 4 incelendiğinde, en yoğun olarak üstünde durulan prensiplerden en az konuşulan prensiplere doğru şu sıranın izlenildiği görülmektedir:

1. İlişkiler prensibi

2. Çocuk imaj1

3. Öğretmenin rolü

4. Proje 
5. Çevrenin rolü

6. Dokümantasyon

$\mathrm{Bu}$ araştırmanın ikinci sorusuna ilişkin bulgular yani sentezlenen çalışmaların Reggio Emilia prensiplerine nasıl uyum sağladığına illişkin bulgular aşağıda sunulmuştur.

\section{Çocuk İmajı}

Bu araştırmada, ortaya çıkan alt temalardan ilki çocuk imajıdır. Reggio Emilia yaklaşımının önemli prensiplerinden biri olan güçlü çocuk imajı, özel gereksinimli çocuklar açısından irdelenmiştir. Reggio Emilia öğretmenleri, özel gereksinimli çocukları "children with special rights” yani “özel hakları olan çocuklar" olarak adlandırmaktadır (Soncini, 2012). Bu mantıkla hareket ederek, özel hakları olan çocuklara bazı ayrıcalıklar tanınmıştır. Ancak, Soncini (Reggio Emilia kasabasındaki okullarında pedagogista olarak çalışmaktadır) bu çocukların kendilerini farklı hissetmemeleri ve gruptan kendilerini soyutlamamaları için, bu ayrıcalıkların doğallaştırıldığını belirtmektedir.

Cox (2017), Reggio Emilia yaklaşımındaki çocuğun özeline inmeyi, her çocuğu kendi özelinde değerlendirmeyi ve çocuğun merak duygusuna verilen önemi, özel hakları olan çocuklar açısından çok kıymetli bulmuştur. Zira her çocuğa aynıymış gibi davranmanın özel hakları olan çocuklar açısından sıkıntılı bir durum olduğunu, ancak Reggio Emilia'da farklılıkların kabul edildiğini ve farklılıklara değer verildiğini belirtmiştir. Ayrıca, Reggio Emilia pedagojisinde, her farklıllğın topluma katkı sağladığının vurgulandığını ve engele takılmadan çocukların içindeki potansiyelin çıkartıldığını belirtmiştir. Soncini (2012) de, Reggio Emilia'ya göre her birimizin farklı olduğunu ve bunun olumlu bir durum olduğunu belirtmiştir. Engel bir farklılık getirir ancak bu her birimizin sahip olduğu farklılıklardan sadece bir tanesidir ve toplumun doğal bir parçasıdır, demiştir. Soncini’ye göre, Reggio Emilia okullarında önemli olan şey toplum olarak elde edilen başarılardır, bireysel başarılar değil.

Çocuk imajı açısından değerlendirildiğinde Gilman (2007) özel hakları olan çocukları güçlü görebilmek için kendinde yaşadığı değişimi şöyle örneklendirmiştir:

Öğretmen (Gilman), dil, motor, duyu ve sosyal gelişim alanlarında engeli olan Jake’in başaramayacağını düşünerek onu dışlamak yerine Reggio'daki gibi “becerili” ve "ilgileri olan” bir birey olarak düşünmek istemiştir. Bir gün boya yapmaları için çocuklardan ilginç/tuhaf materyaller aramalarını ister. Jake de arkadaşlarıyla birlikte ilginç/tuhaf materyaller toplar. Ancak, elinin boyanmasından korkan Jake, bulduğu materyalleri 
boyamada kullanması için arkadaşlarına verir. Aslında daha fazla katılım sağlamak istiyor gibidir. Gilman'ın aklına şöyle bir fikir gelir: Jake’e bir kumaş parçasıyla materyali tutabileceğini ve böylece elinin boyanmayacağını söyler ve önce ona bunu nasıl yapacağını gösterir. Jake de öğretmenin yaptı̆̆ının aynısını dikkatlice yapar ve bağırır “Boyayabiliyorum!” Bu strateji sayesinde Jake etkinliklere katılım sağlamaya ve başka riskler de almaya başlar.

Edmiaston ve Fitzgerald (2000) Reggio Emilia çocuk imajı sayesinde, özel hakları olan çocukların hem etkinliklere katılım hem de etkinliklerde liderlik yapabileceğine örnek vermiştir:

Reggio okulunda gerçekleştirilen gölgeler projesinde, öğretmen çocukları küçük grup çalışması için dörderli gruplara ayırır. Altı hafta boyunca her gün iki kez gölge stüdyosunda birlikte çalışmaya başlarlar. Devamlı aynı çocuklarla çalıştığı için, özel hakları olan çocuk Benjamin- özel arkadaşlık ilişkisi kurma ve hatta liderlik görevleri alma firsatı bulur. Benjamin bir gün gölgeye kendi dinazor oyuncağını katar ve herkesin oynadığı bu gölge oyununu yönlendirme firsatı bulur. Arkadaşları onun liderliğini benimser ve gölge oyununu "dinazor gölge oyunu” olarak devam ettirirler.

Yeni Zellanda'da yürütülen yeni bir araştırmada ise, McAnelly ve Gaffney (2019) özel hakları olan çocukların da güçlü yanlara sahip olabileceğini, karar alabildiğini ve gücünü icra edebildiğini belirtmiş ve anasınıfı öğretmeni Pania’nın deneyimlerini örnek olarak vermiştir:

Pania, daha önce bazı okullarda engeli nedeniyle dışlandığ için o okullardan ayrılan otizm tanılı Tama'nın, kendi okullarında daha güçlü olduğunu, gelişme ve öğrenme açısından yüksek potansiyel sergilediğini belirtmiştir. Tama'nın kendini ifade etmesi için ona uygun dil aradıklarını, bu dil sayesinde Tama'nın gücünün ve öğrendiklerinin başkaları tarafindan görünür hale gelebileceğine inandıklarını dile getirmiştir. Tama'nın annesi de, aslında Tama'nın o kadar da bağımsız olmadığını, sadece uzak durmak isteyen tipik otizmli olduğunu, bu okulda öğretmenlerinin onun çok çaba sarfettiğini vurgulamıştır. Reggio Emilia ilhamlı bu ortamda Tama'nın sevildiğini ve onun da herkesi sevdiğini, kendini güvende ve buraya ait hissettiğini çünkü Tama'nın seçme hakkı olduğunu ve onun seçimlerine saygı duyulduğunu söylemiştir. Tama'nın farklılı̆̆ının bu okulda olumlu olarak algılandığını, genel olarak tüm farklılıkların olumlu bulunduğunu, Tama’nın konuşmalarının başkaları tarafından dinlendiğini ve Tama'nın da bunun farkında olduğunu belirtmiştir. 


\section{Öğretmenin Rolü}

Edmiaston ve Fitzgerald (2000), özel hakları olan çocukların okuduğu Reggio Emilia-ilhamlı okullarında POND adı verilen ekipler olduğunu ve her ekipte öğretmenlerin yanı sıra fazladan özel eğitimci ve yardımcının varolduğunu belirtmiştir. Reggio Emilia yaklaşımına uygun olarak bu ekiplerin işbirliği ve iletişim içinde olduklarını belirtmiştir. Hong ve Shaffer da (2015), özel hakları olan çocukların öğretmenleri ile terapistleri/doktorları arasındaki iletişim kopukluğunun zararlarına değinmiş ve Reggio Emilia-ilhamlı okullarında farklı görevleri olan tüm eğitimcilerin ve hatta dışarıdaki terapist/doktorların çocuklar için takım olmasının önemine değinmiştir.

Hong ve Shaffer'ın (2015) görüşme yaptı̆̆ öğretmenler, terapistle işbirliği yapmanın, hatta özel hakları olan çocukla çalışırken terapistleri seyretmenin kendilerine faydalı olduğunu ve sınıfta o çocukla nasıl çalışacağını anlamalarına yardımcı olduğunu belirtmiştir. Hong ve Shaffer'ın görüşme yaptığı bir terapist de, öğretmenle işbirliğinin kendisine çok iyi geldiğini söylemiş̧tir. Terapist, bu sayede, Reggio Emilia yaklaşımını anladığını, öğretmenlerin sınıfı doğal materyaller ve manipulatiflerle nasıl hazırlandıklarını gördügünü ve ne kadar yaratıcı bir iş yaptıklarına şahit olduğunu belirtmiştir. Kısacası, öğretmenler ve farklı rollerdeki paydaşların takım çalışmasının çocuklar, ebeveynler ve çalışanlar için faydalı olduğunu vurgulamıştır.

Cox (2017) öğretmenin rolünün önemini vurgulamış ve öğretmenin yanısıra okullardaki pedagogista ve atelieristaların (bilim/sanat atölyesinden sorumlu sanatçı) olduğundan ve özel hakları olan çocuklara katkılarından bahsetmiştir. Özel hakları olan çocuklarla ilglili olarak, özellikle atelieristanın çok önemli bir görev üstlendiğini vurgulamıştır. Şöyle ki; atelierista, yaptığ1 atölye çalışmaları sayesinde, özel hakları olan çocukların nasıl öğrendiğini çözmekte ve bu çocukların atölyede değişik deneyimler sahibi olmasını sağlamaktadır.

Thompson da (2006) çalışmasında atelieristanın görevine değinmiş ve atelieristaların çocuğun kendine has öğrenme yolunu bulabilmek için "100 Dil” olarak adlandırılan farklı ifade yollarının kullanımına değinmiștir (örn., sözel ifade, drama yoluyla ifade, kil ile ifade). Öte yandan, okulda, aşçısından temizlikçisine herkesin çocukların gelişiminden ve öğrenmesinden sorumlu olduğunu belirtmiştir. Thompson öğretmenlerin mesleki gelişimleri için ebeveyn, terapist, pedagogista ve çocuğun kendisiyle çalışarak kendilerini geliştirdiklerini belirtmiştir.

Öte yandan, Hong ve Shaffer (2015), öğretmenler ve terapistler gibi paydaşlar farklı yönetimlere tabi olduklarından dolayı işbirliğinde bazen sıkıntılar yaşandığını da belirtmiştir. Örneğin, bütçelerinin ayrı olması, çalışma saatlerinin çakışması, yönetimsel bakış açılarındaki farklılık ve 
bina/alan ortak kullanımındaki zorluklar, işbirliğini zorlaştırmıştır (Hong ve Shaffer, 2015). Bu durum, Hong ve Shaffer'ın yaşadığı, Reggio Emilia yaklaşımına uymayan, olumsuz veri olarak değerlendirilebilir. Nitekim Soncini'nin (2012) belirttiğine göre İtalya'daki Reggio Emilia okullarında görevli olan pedagogistalar hem belediyenin kadrosunda çalışmakta hem de okullarla ilgilenmektedir. Böylece Reggio Emilia okullarının içerideki bağları ve dışarıyla olan bağları çok güçlüdür. Örneğin, bilgi akışı kolaylıkla yapılmaktadır veya çalışma saatleri ortak tek bir yönetim tarafından hazırlanmakta olduğu için çakışmalar olmamaktadır. Bu nedenle Reggio Emilia okullarındaki özel hakları olan çocuklar için öğretmenler ve diğer paydaşlar arasında işbirliğinde aksaklık yaşanmamaktadır.

\section{Proje}

Edmiaston ve Fitzgerald (2000), proje çalışması sayesinde Bireyselleştirilmiş Eğitim Programı (BEP) hedeflerine uygun çalışma yapılabildiğini belirtmiştir. Böylece hem sosyal hem de akademik ihtiyaçlar giderilmektedir. Reggio Emilia yaklaşımına göre "One size fit all” yani "Bir program herkese uyar" anlayışı yoktur, bireyselleştirilmiş eğitim programı vardır.

Soncini (2012) özel hakları olan çocukların akademik boyutta gelişmesinin sağlanması için çeşitli uygulamalar yaptıklarından bahsetmiştir. Bunlar: Dokümantasyon ve gözlem yapmak; tüm çocuklar için olduğu gibi, özel hakları olan çocuğun ilgi ve ihtiyaçlarına uygun olarak eğitim programını yani projelerini düzenlemek; hangi materyal ve stratejilerin kullanılacağına karar vermek ve gerekli çevre düzenlemesini yapmak.

Vakil, Freeman ve Swim (2003), Reggio Emilia yaklaşımını ve farklı programları incelemiş ve şu sonucu varmıştır: Özel hakları olan çocuklar için en az-kısıtlı özgürlük sunan ortamlara ve Gelişimsel Olarak Uygun Uygulamalar yapan eğitim programlarına ihtiyaç vardır ve bunu başarma ve kaynaştırmanın nasıl yapılacağı konusunda Reggio Emilia çok güzel fikirler vermektedir. Zira çocuklara seçme şansı sunan ve çocukların özgürlügünü ve özerkliğini destekleyen proje çalışmaları sayesinde çocuklar, olumlu ilişkilerin kurulduğu grup ortamında bireysel eğitime tabi olmaktadır (Soncini, 2012).

\section{Çevrenin Rolü}

Soncini (2012) Özel hakları olan çocuklar için Reggio Emilia sınıflarında fiziksel düzenlemelerin yapıldığını vurgulamıştır. Örneğin, görme engeli olan bir çocuk için sınıfta yüksek kontrast içeren renklerin kullanıldığı belirtmiştir. Cox (2017), özel hakları olan çocuklar için Reggio Emilia'da 
çevrenin, birlikte düşünmeyi, özgürce hareket etmeyi, keşfetmeyi ve seçim yapmay1 teşvik ettiğini belirtmiştir. Edmiaston ve Fitzgerald da (2000) çevrenin çocuğun ihtiyaçlarına göre şekillendirildiğini belirtmiştir. Mesela, "Picture It" veya "Border Maker" gibi özel gereksinimli çocuklar için tasarlanmış bilgisayar programları kullandıklarını belirtmiştir. Bir başka örnekte de, ayakkabı çeşitlerine ilişkin bir projenin drama çalışmasında ayakkabı dükkanı kurduklarını ve bu ayakkabı dükkanında herkese uygun rol bulduklarını vurgulamıştır. Bu sayede, çevrenin, hem akademik hem de sosyal açıdan özel hakları olan çocukları desteklediğini belirtmiştir.

McAnelly ve Gaffney (2019) Reggio Emilia-ilhamlı okullarında tüm çocuklar ve aileleri için, rahat, sakin, doğal renklerin hakim olduğu, müzik, yumuşak 1şık, hoş koku ve çeşitli dokuların varolduğu bir ortam yarattıklarını vurgulamıştır. Mesela, özel hakları olan bir çocuk olan Tama’nın okullarında çiçeklerle vakit geçirmekten hoşlandığını, onları suladığını ve kokladığını dile getirmiştir. Dışarıda çalılıkların ve bahçenin tüm çocukları heyecanlandırdığını, keşfetme ve öğrenme arzularını harekete geçirdiğini belirtmiştir. McAnelly ve Gaffney, çevre prensibinin özellikle beş duyu organını tetiklemesine vurgu yapmıştır.

Öte yandan, çevre, sınıf başına düşen özel hakları olan çocuk sayısı açısından da iyi tasarlanmalıdır. Soncini (2012) Reggio Emilia okullarında, 20 kişilik bir sınıfa iki taneden fazla özel hakları olan çocuk verilmediğini ve bu sınıfa üçüncü bir öğretmen daha verildiğini velirtmiştir. Bu öğretmenin özel eğitim kökenli öğretmen olmak zorunda olmadığını da vurgulamıştır. Hatta engeli olduğu tespit edilen çocukların Reggio Emilia okullarına kaydında öncelik tanındığını ve hatta okul seçmesine izin verildiğini belirtmiştir. Ancak, Edmiaston ve Fitzgerald (2000) Reggio Emilia ilhamlı Grand Early Childhood Center'da 350 çocuğun \%10’unun özel eğitim için tanılanmış çocuk olduğunu belirtmektedir. Bu oran Reggio Emilia okullarındaki oranın üstündedir.

Thompson (2006) ise Reggio Emilia okullarında çevrenin 3. öğretmen olmasına ve esnek olmasına odaklanmıştır. Reggio Emilia'da çevre esnektir, çocuğun özgürce, yaparak-yaşayarak öğrenmesini destekler ve çok gerekmediği sürece, bu çocukları diğer çocuklardan ayıran mobilyalar kullanılmaz veya etkinlikler yapılmaz. Mesela, özel hakları olan çocuk için gerekli olan destekli-kollu sandalye tüm çocuklar için temin edilir ve gruptan ayrılmaması sağlanır; veya sınıf içinde konuşma terapisi yapılacaksa, isteyen bütün çocukların katılması sağlanır.

\section{Dokümantasyon}

Dokümantasyon ve iyi bir gözlem aracıllğıyla öğretmenler özel hakları olan çocukların potansiyelini görebilmektedir, örneğin bir çocuk materyal keşfine dönük oyunlarda geri durabilir ancak masa 
oyunlarına çok açık olabilir (Soncini, 2012). Dolayısıyla, öğretmen farklı ortamlar yaratmalı ve sonra çocuğu gözlemlemeli ve dokümante etmelidir. Ne kadar farklı ortamda gözlem yaparsa, o kadar çok o çocuğu gerçekten görme ve anlama şansı olur. Bir başka örnekte, dokümantasyon çeşitlerinden biri olan videolar sayesinde, öğretmen farketmediği şeyleri sonradan videoları seyrederken farkedebilir veya çocuk yeni bir öğretmene geçtiğinde, yeni öğretmen bu videoları seyredip, eski öğretmeniyle birlikte o çocuğa ilişkin yorumlar yapmayı çalışabilir (Soncini, 2012).

Cox (2017) dokümantasyon sayesinde yetişkinlerin; çocukların ve ebeveynlerin beyinleriyle diyaloğa girebileceğini yani daha güçlü iletişim kurabileceğini belirtmiştir. Yani dokümantasyon, sağlıklı bir takip ve değerlendirme, aynı zamanda çocukların ve ebeveynlerin katılımını tetikleyen bir araçtır. Bu haliyle dokümantasyon bir ürün çıkartmaya değil, süreci sağlıklı işletmeye yarar (Gandini, 2004). Ancak Knauf (2017), demokratik ve katılımcı bir sistem olan dokümantasyonun, Almanya özelinde çocukların katılımını destekleyip desteklemediğine bakmış ve başarısız olduğunu tespit etmiştir. Almanya genelinde 40 farklı okulda yaptığı çalışmada, dokümantasyonun, poster oluşturma gibi sonuç odaklı olduğunu, çok az okulda gerçekten çocukların dokümantasyon yaptığını yani katılımcı olduğunu bulmuştur. Genel sınıflarda da kaynaştırma sınıflarında da çocukların katılımcı olduğu dokümantasyon çalışmalarının olması gerektiğini vurgulamıştır. Bu durum kısmen olumsuz veri olarak değerlendirilebilir. Öte yandan, genel olarak bakıldığında, bu araştırmanın verilerini oluşturan 12 çalışmanın sadece 4 tanesi dokümantasyon prensibini dikkate almıştır. Bunların bir tanesi zaten Reggio Emilia okullarının pedagogistası Soncini'nin çalışmasıdır. Kısacası, özel hakları olan çocuklar açısından dokümantasyon prensibinin yeterince uygulanmadığı bu araştırmanın önemli sonuçlarından biridir.

\section{İlişkiler}

$\mathrm{Bu}$ araştırmada kaynak verileri sentezlendiğinde ortaya çıkan son ve en yoğun prensip "ilişkiler" prensibi olmuştur. Edmiaston ve Fitzgerald (2000) ilişkinin, çocuk-çocuk, çocuk-öğretmen ve ebeveyn-öğretmen boyutları olduğunu belirtmiştir. Özellikle öğretmen ve tüm çocuklanın topluluk olması açısından önemini vurgulamış ve şöyle bir örnek vermiştir:

Sınıfta öğretmen çocuklara hikaye kitabı okurken, çocuklar, tekerlekli sandalyedeki arkadaşlarının kitabı göremediğini farkederler. Öğretmene Jason'ın kitabı göremediğini söylerler. Jason'ın kitabı görebilmesi için onu doğru pozisyona getirmesini isterler.

Hong, Shaffer ve Han da (2017) ilişkiler prensibini, sınıfta grup bağlarının oluşturulması açısından ele almıştır. Reggio Emilia'da topluluk olma sayesinde, çocukların, özel hakları olan çocuklara karşı 
ilgilerinin, aralarına almalarının, ilişki ve arkadaşlık kurmalarının ve empatilerinin arttığını belirtmiştir. Öte yandan, özel hakları olan çocukların da kazanımlarının olduğunu belirtmiştir. Örneğin, oyun ve proje gruplarına girmede Charles geri çekilme davranışını sürdürürken, Victor'ın geri çekilme davranışını azalttı̆̆ını ve geri çekilme davranışını artık çok nadir sergilemeye başladığını tespit etmiştir. Hong, Shaffer ve Han, sınıfta güçlü ilişkiler kurabilmek için, öğretmenin amaçlı plan yapmasının (intentional planning), dönüşümlü düşünmesinin (reflection) ve çocuklarla birlikte katılımcı olmasının gerektiğini belirtmiştir.

Soncini (2012), ebeveynlerin okula karşı ihtiyaç duydukları güveni inşa etmek amacıyla ailelerle ilişki kurmanın ve aile katılımının çok gerekli olduğunu belirtmiştir. Ev ve okul arasında kesintisiz bir geçiş yaratmak ve çocuğun evdeki tipik hallerini öğrenmek için, bir çocuk Reggio okuluna başlamadan önce öğretmenler ailelerle görüşür. Ebeveynlerin çocuklarının engellerini kabul etmelerine ve engelle ilgili mücadelenin ve korkuların içinde mutluluk bulmalarına yardımcı olur. Reggio Emilia okullarında, farklı olmanın olumlu olarak kabul edildiğini hissettirir. Ailelere, engelli bireyler dâhil herkesin içinde yaşadığı topluma bir katkısı olduğuna inandıkları mesajını verir. Gilman da (2007), ilişkiler prensibinin önemini, ebeveynlerle iletişim ve işbirliği açısından vurgulamıştır. Ancak, işbirliği konusunda başarılı olamadıklarını, aileler ve öğretmen arasında fikir çatışması yaşandığını belirtmiştir. Bazı ebeveynlerin işbirliğine yanaşmadığını, çalışma takvimlerinin dolu olduğunu bahane ederek okula zaman ayırmadıklarını ve katılımcı olmak istemedikleri anlatmıştır. Bu durum, olumsuz veri olarak değerlendirilebilir.

Cox (2017), tüm ilişkilerin değerli olduğunu vurgulamıştır. İlişkilerin güçlü olmasının ve aşçılar, temizlikçiler ve asistanların da çocukların eğitiminden ve gelişiminden sorumlu olmasının Reggio Emilia okullarındaki eğitimin kalitesini artırdığını belirtmektedir. Villines (2011) yürüttüğü tez çalışmasında, Reggio Emilia-ilhamlı anaokulunda, herkesin değerli kabul edildiğini, çalışanların eğitime ihtiyaç duyduğunu, yöneticiler, uzmanlar, öğretmenler ve terapistler arasında destek işbirliğinin ve deneyimlerin başarıyı yükselttiğini tespit etmiştir. Hatta yeni işe başlayan veya stajyer öğretmenlerin de bu desteği hissettiğini ve özel hakları olan çocukların kaynaştırması konusunda başkalarının olumlu deneyimleri hakkında bilgi sahibi olma şansı yakaladığını belirtmiştir. Thompson (2006) Reggio Emilia okullarında ebeveyn, öğretmen, çocuk ve terapist ilişkisine vurgu yapmiştır.

Öte yandan, Yeni Zelanda'da farklı eğitim programlarının uygulandığı okulları inceleyen Macartney ve Morton (2013), özel hakları olan çocukların dışlandığını ve Reggio Emilia'daki gibi bu çocukların dahil edilmesi gerektiğini, bunun için de Reggioca dinleme yani dokümantasyon yapılması 
gerektiğini belirtmiştir. McAnelly ve Gaffney de (2019) Yeni Zelanda'da özel hakları olan çocukların sınıflarda dışlandığını ancak Reggio Emilia yaklaşımı sayesinde bunu aşabildiklerini belirtmiştir.

Thompson (2006) ilişkiler prensibini arkadaşlık ilişkileri açısından değerlendirmiş ve arkadaşlık grupları kurmanın faydalı olduğunu belirtmiştir. Bu gruplarda, özel hakları olan çocukla çalışabilecek en uygun çocuklar seçilir ve onların arkadaşlı̆̆ını geliştirici etkinlikler yapılır. Mesela yüksek sesten rahatsız olan çocuğa, sessiz bir çocukla çalışması teklif edilebilir. Özel hakları olan çocukları anlamak bazen güç olabilir. Ancak Thompson, bu çocukları anlamada, arkadaşlarının yetişkinlerden daha başarılı olduklanını tespit etmiştir. Göstererek veya söyleyerek onların ne demek istediğini anlayabildiklerini bulmuştur. Soncini de (2012) sınıftaki tipik gelişim gösteren çocukların özel hakları olan çocuğu çoğu zaman yetişkinlerden daha iyi anladığını belirtmiştir.

Ayrıca, tipik gelişim gösteren çocuklar, arkadaşlarında gördükleri farklılıklara ilişkin sorular sorabilirler. Thompson’a (2006) göre bu doğaldır ancak üstünde çok durulmamalıdır. Toplantılarda öğretmenler, her çocuğun özel bir tarafinın olduğunu sık sık vurgulamalıdır. Bazı çocuklar köpeklerden korkar, bazı çocuklar işitme cihazı kullanır, bazı çocuklar başkaları tarafından dokunulmayı sevmez gibi. Öte yandan, Thompson'a göre derinlemesine bilgi verilmez, çocuklar kendi aralarında merak ettiklerini birbirine sorabilir, bu dengeyi tutturabilirler. Thompson şöyle bir örnek vermiştir: Mesela, karnında beslenme tüpü olan çocuğa arkadaşları bunun ne olduğunu sordu, o da beslenmesi için olduğunu söyledi. Bu bilgi çocuklara yeterli geldi. Thompson, önceleri çocuklardaki farklılıklardan dolayı arkadaşlarının dalga geçeceğini düşündüğünü ancak çocukları izledikten sonra bunun boşa çıktığını belirtmiştir. Yani çocuklar birbirlerini olduğu gibi kabul etmeye hazırdır. Ayrıca, özel hakları olan çocukların da diğer çocuklara katkısı vardır. Örneğin, babası kanserden ölmek üzere olan bir çocuk her gün okulda doktorculuk oynamakta, arkadaşlarının yatağa uzanmasını isteyip, doktor olmaktadır. Tipik gelişim gösteren arkadaşları her gün aynı oyunu tekrar tekrar oynamaktan sıkılır. Ancak Down sendromlu çocuk bu oyunu onunla oynamaktan mutluluk duymaktadır (Thompson, 2006).

Son olarak Thompson, topluluk olma ruhu sayesinde, çocukların birlikte problemlere çözüm üretebildiklerinden bahsetmiştir. Çocuklar, yaşadıkları problemlerin sonuçlarını ve kendi üzerlerinde bıraktığı etkileri tartısıllar ve sonra birlikte nasıl çözeceklerine dair çözümler üretirler. Kısacası, Reggio Emilia okullarında topluluk olmak çok önemlidir. Örneğin, hastaneye yatırılan özel hakları olan bir çocuk (ITP) "Ailemin yanına gitmek istiyorum.” demiştir. Ailesi, "Biz buradayız." dediğinde "Hayır! Okul ailemi istiyorum.” demiştir. Bu örnekte de görüldüğü gibi, Reggio Emilia yaklaşımı, özel hakları olan çocukların kaynaştırma çalışmalarında onların topluluğun bir parçası 
olmasını çok önemsemektedir. Ancak Soncini’ye (2012) göre özel hakları olan çocukların kaynaştırması sadece okulun duvarları arasında yapılmamalıdır. Bu çocukların tüm şehirde nasıl kaynaştırılacağı konuşulmalıdır. Örneğin mimarlar, şehir planlamacıları ve tasarımcılar da bu çocukların topluma nasıl dahil edileceğini düşünmesi gerekir.

\section{SONUÇ VE TARTIŞMA}

$\mathrm{Bu}$ araştırmada meta-etnografik çalışmaların doğası gereği, her bir veri kaynağı, canlı örnekleriyle yani var olan durumuyla sunulmuş ve tüm kaynaklar bu şekilde sentezlenmiştir. Yani tüm metaetnografik çalışmalarda olduğu gibi (Borgnakke, 2017; Kakos ve Fritzsche, 2017; Mertala, 2019) bu araştırmanın amacı genelleme yapmak ve istatistitiksel sonuçlar çıartmak değildir. Ancak prensipler açısından genel tabloyu görmek amacıyla kümülatif bir bakış açısıyla da bakılmıştır.

$\mathrm{Bu}$ kümülatif bakış açısından yola çıkılarak araştırmanın birinci sorusu olan Reggio Emilia yaklaşımını esas alan kaynaştırma eğitimi araştırmalarının, altı ana prensipten (çocuk imajı, öğretmen rolü, proje, çevrenin rolü, dokümantasyon, ilişkiler) hangisine/hangilerine uyum sağladığına ilişkin sorusuna yanıt aranmıştır. Sonuç olarak, Reggio Emilia yaklaşımını esas almış okul öncesi eğitim kurumlarında özel hakları olan çocuklara dair yapılan çalışmalar incelendiğinde, en yoğun olarak üstünde durulan prensiplerden en az üstünde durulan prensiplere doğru şu sıranın izlendiği bulunmuştur:

1. İlişkiler prensibi

2. Çocuk imaj1

3. Öğretmenin rolü

4. Proje

5. Çevrenin rolü

6. Dokümantasyon

İlişkiler prensibi üzerinde yoğun çalışmalar yapılırken, dokümantasyon prensibi üzerince yeterince çalışmanın yapılmadığı tespit edilmiştir. Hâlbuki her prensip eşit derecede öneme sahiptir ve Reggio Emilia yaklaşımını esas alan tüm okullarda bu prensiplerin bir bütün olarak uygulanması gerektiği unutulmamalıdır. Bu meta-etnografik araştırma, Reggio Emilia yaklaşımın bazı parçalarının yeterince değerlendirilmediğini ortaya koymuştur.

Araştırmanın ikinci sorusu olan Reggio Emilia yaklaşımını esas alan kaynaştırma eğitimi araştırmalarının Reggio Emilia prensiplerine nasıl uyum sağlandığına ilişkin sorusuna uygun olarak 
yapılan derinlemesine incelemede ise yoğun olarak üzerinde durulan prensiplerin bile Reggio Emilia yaklaşımında varolduğu kadar içselleştirilemediği görülmektedir. Örneğin, çocuk imajı prensibi; farklılıklar, farklıların getirdiği çeşitlilik ve potansiyel, haklar (yani, iyi bir binada eğitim alma hakkı, iyi eğitimcilere sahip olma hakkı, doğru zamanda iyi etkinlikler yapma hakkı), her çocuğun güçlü, ilgili, meraklı ve güzel olduğu vurgulamaktadır (Malaguzzi, 1994; Malaguzzi, 1998). Hatta özel gereksinimli çocuklar terimi yerine özel hakları olan çocuklar teriminin kullanılması da Reggio Emilia'da çocuklara ne kadar çok değer verildiğinin bir kanıtır (Philips, 2001). "Özel gereksinim” teriminden "özel haklar” terimine geçiş sadece çocuk hakları açısından değil, linguistik olarak insanlar üzerinde yarattığı etki açısından da çok önemlidir (Runswick-Cole, Hodge, 2009). Zira, Runswick-Cole ve Hodge'ın yaptığı söylem analizine göre -Beresford dilde değissikliğin tek başına uygulamayı değiştiremediğini söylese de- tecrübeler göstermiştir ki "eğitim hakları" söylemi hem eğitimin sağlanmasını hem de uygulanması artırmaktadır.

Ancak, bu araştırma kapsamında incelenen çalışmalarda, çocuk imajına ilişkin olarak örneğin çocukların ilgilerine hiç odaklanılmamışır. Reggio Emilia'da geliştirilen projeler çocukların ilgi ve ihtiyaçlarından yola çıkılarak oluşturulduğu düşünüldüğünde (Rinaldi, 1993; Rinaldi, 1998), bu veri kaynaklarındaki çocuk imajına dair bulgularda "ilgi” konusuna rastlanmaması, bu okullarda çocuk imajını yeterince içselleştiremediklerini akla getirmektedir. Öte yandan, ilgili veri kaynakları çoğunlukla çocuğun güçlü olmasına odaklanmıştır. Batılı ülkelerde, özel hakları olan çocukların, engelli ve eksik olarak adlandırıldıkları sıkça vurgulanmaktadır (Fielding, 1995; Lewin-Benham, 2006; Loreman, 2007; Sellars, 2006). Ancak bu çocuklar Reggio Emilia'da güçlü olarak tanımlanmaktadırlar ve etiketleme veya katı değerlendirmeler yapılmamaktadır (puan verme gibi). Çünkü herkesin doğuştan öğrenmeye açık olduğuna inanılır ve ev atmosferinde çocukların aynı öğretmenle ve aynı çocuklarla üç yıl boyunca birlikte olması sağlanır (Palestis, 1994). Kısacası, Reggio Emilia öğretmenleri, birlikte çalıştıkları çocukların güçlü yanlarını, meraklarını, ilgilerini, onlanı neyi motive ettiğini iyi bilirler ve ona göre eğitim faaliyetlerini ve proje çalışmalarını sürdürürler (Malaguzzi, 1994). Ayrıca Reggio Emilia yaklaşımının önde gelenlerinden Lella Gandini (1997), toplumun yüksek kaliteli okul öncesi eğitiminin önemini kavramastyla ve her çocuğun eğitim hakkı olduğuna inanmasıyla birlikte, çocuklar için uygun çevrelerin yaratılacağı ve çocukların potansiyellerini kullanma şansı yakalayacaklarını belirtmiştir. Görüldüğü üzere, Reggio Emilia yaklaşımında çocuk imajı, çocuğun güçlü olmasından daha geniş bir kapsama sahiptir.

Bu araştırmada, öğretmen rolü prensibine ilişkin bulguların da kapsamlı olmadığ1 tespit edilmiştir. Veriler göstermiştir ki, öğretmen rolü prensibine uygun olarak öğretmenlerin diğer paydaşlarla işbirliği yapması, atelierista ve pedagogistanın görevlerini yerine getirmesi ve çocukların kendilerini 
ifade etmek için sözel ifadenin dışında, görsel sanatlar gibi birçok yol olduğuna işaret eden 100 Dil kullanımı vurgulanmaktadır. Öte yandan, bu araştırma göstermiştir ki, Reggio Emilia-ilhamlı okullarda öğretmenlerin özel hakları olan çocuklara ilişkin görevlerini yerine getirirken, tüm rollerini [örneğin, gözlemci, dinleyici, öğrenci, bakıc1, arkadaş ve provokatör (Rinaldi, 1993)] nasıl uygulamaya koyduğuna dair daha fazla veriye ve atelierista ve padagosistanın çalışmalarına ve 100 Dil anlayışına dair daha yoğun kanıtlara ihtiyaç vardır. Örneğin 100 Dil, özel hakları olan çocuklar açısından çok gerekli olduğundan daha yoğun uygulamaya konulmalıdır. Bu konuya paralel olarak, Mitchiner, Batamula ve Kite (2018) işitme engelliler okulunda Reggio Emilia yaklaşımından ilham alarak gerçekleştirdikleri eğitimde 100 Dil anlayışına uyduklarını yani, çocukların kendilerini ifade etmeleri için sadece sözel dil değil başka yollar da sunduklarını (örn., yazılı dili, sözlü dil ve işaret dili), böylece çocukların düşüncelerini ve duygularını daha rahat ifade edebildiklerini ve kendilerine daha fazla güvendiklerini bulmuştur. Heredia da (2017), Reggio Emilia okullarında, sanatla bütünleştirilmiş programın, sanat materyallerinin, duyu etkinliklerinin, rastgele bulunmuş objelerin ve gevşek parçaların (loose parts), yeni fikirleri ve duyusal bilgileri (sensations) keşfetme açısından çocuklara sınırsız fırsat sunduğunu, açık bir çevrenin de iletişim kurma ve sosyalleşmeyi tetiklediğini belirtmiştir. Heredia, yürüttüğü tez çalışmasında, sanatla bütünleştirilmiş eğitimin, özel hakları olan çocukların sosyal-duygusal gelişimlerinde katalist etkisi yarattığını ve kendilerini düzenlemelerine ve kendilerine ilişkin farkındalıklarının artmasını direk olarak etkilediğini tespit etmiştir.

Kaynak verileri proje prensibi açısından sentezlendiğinde ise, tüm çocuklar için olduğu gibi özel hakları olan çocuklar için de bireyselleştirilmiş program oluşturulduğu vurgulanmıştır. Ancak daha fazla detaylı bulguya ihtiyaç vardır. Zira Reggio Emilia yaklaşımının en önemli özelliklerinden biri, çocukların hazır bir müfredata tabi olmaması ve onların ilgi ve ihtiyaçlarından yola çıkılarak gerçekleştirilen uzun süreli ve kısa süreli proje çalışmalarının olmasıdır (Inan, Trundle, KantorMartin, 2010). Smith (1998) küçük grup proje çalısmaları sayesinde özel hakları olan çocukların okula isteyerek geldiğini ve özerklik duygusunun geliştiğini belirtmiştir. Bunun nedeni de özel hakları olan çocukların küçük gruplarda daha rahat olması ve daha etkin çalışabilmesidir (Palsha, 2002).

Bir diğer prensip çevre prensibidir. Kaynak verileri incelendiğinde çevrenin farklı boyutlarda dikkate alındığı görülmektedir. Özellikle çevrenin bütün çocuklara hitap edecek şekilde tasarlanması, zengin ve rahat çevrelerin oluşturulması, hem akademik hem de sosyal açıdan çocukları desteyecek şekilde donatılması, kapsayıcılığın daha iyi olması için sınıf başına düşen çocuk sayısı gibi faktörülerin dikkate alınması ve tüm çocuklar için olduğu gibi özel hakları olan çocuklar için de maksimum özgürlük minimum kısıtl1lık ilkesinin düşünüldüğü vurgulanmıştır. Öte yandan, 
bulgularda olumsuz örneklere de rastlanmıştır. Örneğin bir sınıfa ikiden fazla özel hakları olan çocucuğun verilmesi. Hâlbuki İtalya'daki Reggio Emilia okullarında bir sınıfa özel hakları olan en fazla bir veya iki çocuk verilmektedir (Morrison, 2000; Smith, 1998; Soncini, 2012). Morrison, 75100 çocuklu bir Reggio Emilia okuluna özel hakları olan 3-4 çocuk kabul edildiğini, eğer okul dolu ise diğer bir okula yönlendirildiğini belirtmiştir. Bu sınıflara fazladan öğretmen alındığını bu öğretmenlerin özel eğitim hakkında eğitim almalarının zorunlu olmadığını; ancak özel eğitim hakkında eğitim alan öğretmenlerin tercih edildiğini belirtmiştir. Pedagogistaların bu öğretmenlere eğitim verdiğini de eklemiştir. Ancak sınıfta DEHB yani dikkat eksikliği ve hiperaktivite bozukluğu yaşayan çocuklar için hiçbir şey yapılmadığı zaten fazladan bir şey yapmaya gerek olmadığına inandıklarını vurgulamıştır. İhtiyaç duyulursa, özel hakları olan çocukların, bir sene fazladan okulda kalabildiklerini söylemiştir. Mümkünse sınıflarda işaret dilinin kullanılmaya çalışıldığını da eklemiştir.

Çevre prensibinin tüm boyutlarıyla ele alınması önemlidir zira Reggio Emilia yaklaşımında çevre 3. öğretmen olarak ele alınmakta ve çocukların eğitiminde ve gelişiminde çok önemli bir rol oynadığ1 vurgulanmaktadır. Bu anlayışa paralel olarak, Vouros da (t/y) otizm spektrumunda Amerika Birleşik Devletleri'nde sıkça kullanılan Uygulamalı Davranış Analizi'nin yanı sıra Reggio Emilia yaklaşımından faydalanılması gerektiğini vurgulamıştır. Vouros, Reggio Emilia yaklaşımı sayesinde, özellikle öğrenme bozukluğu yaşayan çocukların duyularına, çevresine, istek ve meraklarına daha fazla odaklanılacağından, daha etkili öğrenmelerin gerçekleşeceğini belirtmiştir.

Dokümantasyon da bir diğer prensip olarak karşımıza çıkmaktadır. Sonuç değil süreç odaklı bir çalışma olan dokümantasyon sayesinde özel hakları olan çocukların çalışmaları ve ilerlemesi pedagojik amaçlı olarak devamlı takip edilir, değerlendirme yapılır ve buna uygun olarak program geliştirilir (Gandini, 2004; Rinaldi, 1998; Rinaldi, 2004; Rinaldi, 2006; Smith, 1998; Soncini, 2012). Yine dokümantasyon sayesinde özel hakları olan çocukların aileleri, çocukların okulda ne yaptıkları ve diğer çocuklarla ilişkisi hakkında bilgi alabilir (Morrison, 2000). Yazılı, görsel ve video gibi farklı türlerde olabilen dokümantasyon belgeleri çocukları anlamak ve onların kendilerini daha iyi anlatabilmesi için farklı yollar bulabilmek için kullanılır (Forman ve Fyfe, 1998). Forman ve Fyfe'a göre dokümantasyon sayesinde eğitimciler çocukların şemasını, duygularını, ilgilerini ve yeteneklerini anlayabilir ve buna uygun olarak anlamlı ve geliştirici deneyimler hazırlayabilir. Ancak, bu araştırmanın bulguları göstermiştir ki, özel hakları olan çocuklar açısından dokümantasyon prensibi yeterince uygulamaya konulmamaktadır. 
Bir diğer ve sonuncu prensip ise ilişkiler prensibidir. Reggio Emilia kollektivist kültürün gereği olarak çocuklar, aileler, okul, toplum ve çevre arasındaki bağ1 güçlü tutar ve bu durum Reggio Emilia yaklaşımında "ilisskiler" prensibi olarak adlandırılır (Malaguzzi, 1993; Rinaldi, 1998). Nutbrown ve Clough (2004) dört farklı ülkede 113 Avrupalı eğitimci üzerinde yürüttüğü araştırmada, bireyselci bir kültür ile kollektivist bir kültüre sahip olmanın fark yarattığını, Reggio Emilia okullarının bu yüzden kaynaştırmada başarılı olduklarını belirtmiştir. Zira daha ilk adımda Reggio Emilia kasabasında, çocuklar kendi yaşadıkları yerdeki okula yerleştirilirler ve böylece hem ailelerin hem de çocukların zaten içinde yaşadıkları topluluk içinde okula başlamaları sağlanır (Nurse, 2001). Araştırmanın bulgularında da görüldüğü üzere, ilişkiler prensibi kaynak verilerde en yoğun uygulanan prensip olarak karşımıza çıkmaktadır. Sosyo-kültürel anlayışa uygun olarak çocukların gelişmesini ve öğrenmesini ilişkilerin farklı boyutlarını kullanarak desteklemektedir. Bu boyutlar; toplum, öğretmenler, aileler, çocuklar ve hatta aşçlar, temizlikçiler ve asistanlar olarak kaynak verilerde kendilerini göstermektedir. Öte yandan, bu boyutlann kendi içinde ve birbirleriyle nasıl sağlam bağlantılar kurduğu ifade edilmiştir. Sonuç olarak, özel hakları olan çocuklar, Reggio Emilia-ilhamlı okullarda ve Reggio Emilia okullarında kendilerini evlerinde gibi hissetmektedir. $\mathrm{Bu}$ bağlamda, Türkiyedeki erken çocukluk eğitim merkezlerinde de, Reggio Emilia yaklaşımdan ilham alarak, kaynaştırma çocukları için kendilerini ait hissettikleri okullar inşaa etmek mümkün olacaktır.

Araştırma sonuçlarına göre, farklı ülkelerde bulunan Reggio Emilia ilhamlı okullarda uygulanan kaynaştırma eğitimi, İtalyadaki Reggio Emilia okullarındaki gibi kapsamlı olarak ele alınmamaktadır. Bu sentezleme çalışmasına dayanarak, Reggio Emilia ilhamlı okullardaki kapsamlı bir kaynaştırma eğitimi için tüm prensiplerin gereğince uygulamaya konulması gerektiği söylenebilir. Son olarak, Reggio Emilia yaklaşımına uygun olarak kaynaştırma eğitimi yapmak isteyen eğitimciler için ilk başta izlenebilecek adımlar için şu öneriler yapılabilir:

\section{Okula başlamadan önce yapilacaklar:}

- Okul ve sağlık hizmetleri arasında bağlantıyı kurmakla görevli pedagogista (eğitim uzmanı), aileyle işbirliği yaparak çocuğun ilgilerini tespit etmelidir ve onu motive eden konuların ne olduğunu bulmalıdır.

- Dokümantasyon ve dikkatli bir gözlem yapılarak çocuğun ilgi ve motivasyon kaynakları tespit edilmelidir.

- Öğretmen ev ziyaretleri yaparak, çocuğun çevreyi nasıl kullandığını ve ebeveynlerinin ne stratejiler kullandığını gözlemlemelidir. 
- Çocukların farklı seviyelerdeki gelişimleri ve farklılıkları, grup öğrenme yaklaşımıyla desteklenmelidir.

- Reggio öğretmenleri özel eğitim almazlar ancak çocuk okula başlamadan önce çocuk hakkında ve onun ihtiyaçları hakkında olabildiğince çok şey öğrenmeye çalışmalıdır. Bunun için öğretmen, ebeveyn, çocuk doktoru ve pedagogista işbirliği yapmalıdır.

- Bir sonraki adımda, öğretmen, yeni arkadaşları için sınıftaki çocukları hazırlamalı ve hep birlikte onu nasıl karşılayacaklarının planını yapmalıdır.

\section{Okula başladıktan sonra yapılacaklar:}

- Engelin bu çocukları nasıl etkilediğine bakılmalı, önyargıyla yaklaşmadan bütün olarak çocuk değerlendirilmelidir.

- Her sınıfa sadece bir özel hakları olan çocuk yerleştirmeli ve o sınıfa da fazladan bir destek öğretmeni verilmelidir. Ancak bu öğretmen bütün çocuklarla ilgilenmelidir

- Eğer 20 kişilik bir sınıfa iki özel hakları olan çocuk yerleştirilecekse, ikisinin farklı gereksinimleri olan çocuklar olması sağlanmalıdır.

- Ağır bir engel olmadıkça, özel bir muamele yapılmamalı, ancak diğer çocuklar gibi o da öğretmenin özel radarında olmalıdır.

D Dokümantasyon aracilığıla, öğretmenler her bir çocuğun ilgi ve ihtiyacına göre eğitim programını hazırlamalıdır. Çocuğun neyle ilgilendiğini tespit etmek için devamlı gözlem, yorum ve değerlendirme içeren dokümantasyon yapılmalıdır.

- Çoğu zaman eğitim programları çocukları etiketlendirir ve daha kolay öğrenmeleri için gruplandırır, ancak Reggio Emilia okullarında her çocuk yaratıcı ve becerikli olarak görülür. Her çocuk şu anki anlayışına, geçmiş deneyimlerine uygun olarak ve öğretmenin provokasyonları sayesinde yeni bilgiler yapılandırır. Dolayısıyla, bir çocuğun ne kadar ilerleyeceğinin o çocuğa özgü olduğu unutulmamalıdır. 


\section{KAYNAKÇA}

Bailey, D. B. \& Wolery, M. (1992). Teaching infants and preschoolers with disabilities (2 ${ }^{\text {nd }}$ ed.). New York: Merrill.

Borgnakke, K. (2017). Meta-ethnography and systematic reviews - linked to the evidence movement and caught in a dilemma. Ethnography and Education, 12(2), 194-210.

Cadwell, L. B. (2011). Reggio Emilia yöntemiyle barika çocuk yetiştirmek: Eğitimciler ve anne babalar için. İstanbul: Kaknüs Yayınları.

Cagliari, P., Soncini, I., \& Nicolosi, M. (2019). Rights, differences, participation, and democracy. Innovations in Early Education: The International Reggio Exchange, 26(1), 4-11.

Campbell, R., Pound, P., Morgan, M., Daker-White, G., Britten, N., Pill, R., et al. (2011). Evaluating meta-ethnography: Systematic analysis and synthesis of qualitative research. Health Technology Assessment, 15(43), i-164. DOI: 10.3310/hta15430

Ceppi, G. \& Zini, M. (Eds.). (1998). Children, spaces, relations: Metaproject for an environment for young children. Reggio Emilia, Italy: Reggio Children.

Creswell, J. W. \& Miller, D. L. (2000). Determining validity in qualitative inquiry. Theory Into Practice, 39, 124-130.

Cox, L. (2017). Children with special rights in Reggio Emilia - A story of the possible. International Educator, 31(4), 10-33.

Dahlberg, G. (2000). Everything is a beginning and everything is dangerous: some reflections on the Reggio Emilia experience. In H. Penn (Ed.), Early childhood services theory, policy and practice (pp. 175-183). Philadelphia: Open Univesity Press.

Edmiaston, R. \& Fitzgerald, L.M. (2000). How Reggio Emilia encourages inclusion. Educational Leadership 58(1), 66.

Edwards, C. P. (1998). Partner, nurturer, and guide: The role of the teacher. In C. Edwards, L. Gandini, \& G. Forman (Eds.), The hundred languages of children: the Reggio Emilia approachadvanced reflections (pp. 179-198). Greenwich: Ablex.

Edwards, C., Gandini, L., \& Forman, G. E. (2012). Introduction: Background and starting points. In C. Edwards, L. Gandini, \& G. E. Forman (Eds.), The hundred languages of children: The Reggio Emilia experience in transformation (3rd ed., pp. 5-26). Oxford, England: Praeger.

Emilia Romagna. (1993). Children in Reggio Emilia look at their school. Children's Environments, 10(2), 126-129.

Ellis, C. (2009). Revision: autoethnographic reflections of life and work. Walnut Creek, CA: Left Coast Press.

Elsevier (2020). A guide for writing scholarly articles or reviews for the Educational Research Review. $21 \quad$ Mayis $\quad 2020 \quad$ tarihinde https://www.elsevier.com/_data/promis_misc/edurevReviewPaperWriting.pdf adresinden erişildi. 
Fielding, E. N. (1995). Teaching to the strengths. Reading Today, 13(1), 29.

Filippini, T. (1998). The role of the pedagogista: An interview with Lella Gandini. In C. Edwards, L. Gandini, \& G. Forman (Eds.), The hundred languages of the children: The Reggio Emilia approachadvanced reflections (pp. 127-138). Greenwich: Ablex.

Forman, G. \& Fyfe, B. (1998). Negotiated learning through design, documentation and discourse. In C. Edwards, L. Gandini, \& G. Forman (Eds.), The hundred languages of children: The Reggio Emilia approach-advanced reflections (pp. 239-260). Greenwich: Ablex.

Gandini, L. (1997). Foundations of the Reggio Emilia approach. In J. Hendrick (Ed.), First steps toward teaching the Reggio way (pp. 14-25). Upper Saddle River, N.J.: Merrill.

Gandini, L. (1998). Educational and caring spaces. In C. Edwards, L. Gandini, \& G. Forman (Eds.), The bundred languages of children: The Reggio Emilia approach-advanced reflections (2nd ed., pp. 161178). Greenwich, Conn: Ablex.

Gandini, L. (2002). The story and foundations of the Reggio Emilia approach. In V. R. Fu, A. J. Stremmel, \& L. T. Hill (Eds.), Teaching and learning: Collaborative exploration of the Reggio Emilia approach (pp. 13-21). Upper Saddle River, N.J.: Merrill.

Gandini, L. (2004). Foundations of the Reggio Emilia approach. In J. Hendrick (Ed.), Next steps toward teaching the Reggio way: Accepting the challenge to change (2nd ed., pp. 13-26). Upper Saddle River, N.J.: Pearson/Merrill/Prentice Hall.

Gandini, L., Hill, L., Cadwell, L., \& Schwall, C. (2005). In the spirit of the studio: Learning from the atelier of Reggio Emilia (Early Childhood Education Series). New York: Teachers College Press.

Gandini, L. \& Kaminsky, J. (2006). To know a child with special rights: An interview with Ivana Soncini. Innovations in Early Education: The International Reggio Exchange, 13(1), 1-11.

Gilman, S. (2007). Including the child with special needs: Learning from Reggio Emilia. Theory into Practice, 46(1), 23-31. DOI: $10.1080 / 00405840709336545$

Gürgür, H. \& Hasanoğlu Yazçayır, G. (2019). Türkiye'de kaynaştırma eğitimine yönelik öğretmenlerin görüşlerine odaklanılmış lisansüstü eğitim tezlerinin sentezlenmesi: metaetnografik bir çalışma. Eğitimde Nitel Araștırmalar Dergisi - Journal of Qualitative Research in Education, 7(2), 845-872.

Heredia, M. S. (2017). Implementing arts-integrated programs in early childhood education settings. Yayımlanmamış Yüksek Lisans Tezi, Mills College, California.

Hong, S. B. \& Shaffer, L. S. (2015). Inter-professional collaboration: Early childhood educators and medical therapist working within a collaboration. Journal of Education and Training Studies, 3(1), 135-145.

Hong, S.B., Shaffer, L., \& Han, J. (2017). Reggio Emilia inspired learning groups: Relationships, communication, cognition, and play. Early Childhood Education Journal, 45(5), 629-639.

Hughes, S. \& Noblit, G. (2017). Meta-ethnography of autoethnographies: A worked example of the method using educational studies. Ethnography and Education, 12(2), 211-227. 
Inan, H.Z., Trundle, K.C., \& Kantor-Martin, R. (2010). Understanding natural sciences education in a Reggio Emilia-inspired preschool. Journal of Research in Science Teaching, 47(10), 11861208.

İnan, H.Z. (2012). Okul öncesi eğitiminde çağdass yaklaşımlar: Reggio Emilia ve Proje Yaklaşımı. Ankara: Anı Yayincilik.

Kakos, M. \& Fritzsche, B. (2017). Meta-ethnography E\&E. Ethnography and Education, 12(2), 129133. DOI: $10.1080 / 17457823.2017 .1278578$

Knauf, H. (2017). Documentation as a tool for participation in German early childhood education and care. European Early Childhood Education Research Journal, 25(1), 19-35.

Lewin-Benham, A. (Foreword by H. Gardner). (2006). Possible schools: The Reggio approach to urban education. New York: Teachers College Press.

Loreman, T. (2007). How we view young children with diverse abilities: What Canada can learn from Reggio Emilia. Exceptionality Education Canada, 17(1), 5-26.

Macartney, B. \& Morton, M. (2013). Kinds of participation: Teacher and special education perceptions and practices of 'inclusion' in early childhood and primary school settings. International Journal of Inclusive Education, 17(8), 776-792.

Malaguzzi, L. (1993). For an education based on relationships. Young Children, 49(1), 9-12.

Malaguzzi, L. (1994). Your image of the child: Where teaching begins. Child Care Information Exchange, 96, 52-61.

Malaguzzi, L. (1998). History, ideas, and basic philosophy: An interview with Lella Gandini. C. Edwards, L. Gandini, \& G. Forman (Eds.), The hundred languages of children: The Reggio Emilia approach-advanced reflections (2nd ed., pp. 49-97). Greenwich, CT: Ablex Publishing Corporation.

Malaguzzi, L. (tarih yok). Values. 5 Ocak 2020 tarihinde https://www.reggiochildren.it/en/reggioemilia-approach/valori-en/ adresinden erişildi.

Mallory, B. L. \& New, R. S. (1994). Social constructivist theory and principles of inclusion: Challenges for early childhood special education. The Journal of Special Education, 28(3), 322337. DOI: $10.1177 / 002246699402800307$

McAnelly, K. \& Gaffney, M. (2019). Rights, inclusion and citizenship: A good news story about learning in the early years. International Journal of Inclusive Education, 23(10), 1081-1094.

Mertala, P. (2019). Teachers' beliefs about technology integration in early childhood education: A meta-ethnographical synthesis of qualitative research. Computers in Human Behavior, 101, 334349.

Mitchiner, J., Batamula, C., \& Kite, B. J. (2018). Hundred languages of deaf children: Exploring the Reggio Emilia approach in deaf education. American Annals of the Deaf, 163(3), 294-327. 
Morrison, N. (2000). The Reggio approach: An inspiration for inclusion of children with "special rights." Delta Kappa Gamma Bulletin, 66(3), 35-44.

New, R. S. (2007). Reggio Emilia as cultural activity theory in practice. Theory Into Practice, 46(1), 513.

Noblit, G. W. \& Hare, R. D. (1988). Meta-ethnography: Synthesising qualitative studies. London: Sage publication. $\quad 31 \quad$ Ağustos $2019 \quad$ tarihinde http://www.sagepub.com/booksProdDesc.nav?prodId=Book2416 adresinden erişildi.

Noyes, J. (2006). The use of meta-ethnography in synthesising qualitative research findings. 16 Haziran 2020 tarihinde http://stti.confex.com/stti/congrs06/techprogram/paper_30033.htm adresinden erişildi.

Nurse, A. (2001). A question of inclusion. In L. Abbott \& C. Nutbrown (Eds.), Experiencing Reggio Emilia: Implications for pre-school provision (pp. 62-71). Philadelphia: Open University Press.

Nutbrown, C. \& Clough, P. (2004). Inclusion and exclusion in the early years: Conversations with European educators. European Journal of Special Needs Education, 19(3), 301-315. DOI: $10.1080 / 0885625042000262479$

Palestis, E. (1994). The Reggio way. The American School Board Journal, 181(8), 32- 35.

Palsha, S. (2002). An outstanding education for ALL children: Learning from Reggio Emilia's approach to inclusion. In V. R. Fu, A. J. Stremmel, \& L. T. Hill (Eds.), Teaching and Learning: Collaborative exploration of the Reggio Emilia approach (pp. 109-130). Upper Saddle River, NJ: Merrill Prentice Hall.

Philips, S. (2001). Special needs or special rights? In L. Abbott \& C. Nutbrown (Eds.), Experiencing Reggio Emilia: Implications for pre-school provision (pp. 48-61). Philadelphia: Open University Press.

Rinaldi, C. (1993). The emergent curriculum and social constructivism: An interview with Lella Gandini. In C. Edwards, L. Gandini, \& G. Forman (Eds.), The hundred languages of children: the Reggio Emilia approach to early childhood education (pp. 101-112). Norwood, NJ: Ablex Pub. Corp.

Rinaldi, C. (1998). Projected curriculum constructed through documentation - Progettazione: An interview with Leila Gandini. In C. Edwards, L. Gandini \& G. Forman (Eds). The hundred languages of children: The Reggio Emilia approach - advanced reflections (pp. 49-97). Greenwich, CT: Ablex Publishing Co.

Rinaldi, C. (2004). The relationship between documentation and assessment. Innovations in Early Childhood: The International Reggio Exchange, 11(1), 1-4.

Rinaldi, C. (2006). In dialogue with Reggio Emilia listening, researching and learning (1st ed.). New York: Routledge.

Runswick-Cole, K. \& Hodge, N. (2009). Needs or rights? A challenge to the discourse of special education. British Journal of Special Education (BJSE), 36(4), 198-203. 
Sandall, S. \& Ostrosky, M. (2000). A message from the editors. In S. Sandall \& M. Ostrosky (Eds.), Natural environments and inclusion (pp. v-vi). Denver, CO: Division for Early Childhood of the Council for Exceptional Children.

Sellars, G. (2006). Learning to communicate with children with disabilities. Paediatric Nursing, 18(9), 26-8.

Shepherd, W. \& Eaton, J. (1997). Creating environments that intrigue and delight children and adults. Child Care Information Exchange, 9, 42-47.

Smith, C. (1998). Children with "special rights" in the preprimary schools and infant-toddler centers of Reggio Emilia. In C. Edwards, L Gandini \& G. Forman (Eds). The hundred languages of children: The Reggio Emilia approach - advanced reflections (pp. 199-214). Greenwich, CT: Ablex Publishing Co.

Soncini, I. (2012). The inclusive community. In C. Edwards, L. Gandini, \& G. E. Forman (Eds.), The bundred languages of children: The Reggio Emilia experience in transformation (3rd ed., pp. 187212). Oxford, England: Praeger.

Spradley, J. P. (1980). Participant observation. New York: Holt, Rinehart and Winston.

Thompson, N. (2006). «She is our little sister» reflections about inclusion. Innovations in Early Education: The International Reggio Exchange, 13(1), 12-20.

Thornton, L. \& Brunton, P. (2010). Bringing the Reggio approach to your early years practice (2nd ed.). London: Routledge.

Thornton, L. \& Brunton, P. (2015). Understanding the Reggio approach (3rd ed.). London: David Fulton Publishers.

Vakil, S., Freeman, R., Swim, T.J. (2003). The Reggio Emilia approach and inclusive early childhood programs. Early Childhood Education Journal, 30(3), 187.

Villines, M. (2011). Early childhood inclusion: Teacherperception of the supports needed to fully include children with special needs. Yayımlanmamış Yüksek Lisans Tezi, Portland State Üniversitesi, Portland.

Vouros, A. (tarih yok). Children on the autism spectrum and the Reggio Emilia approach. 31 Ağustos 2019 tarihinde https://docplayer.net/21530018-Alexa-vouros-autism-spectrumdisorder-now-affects-over-two-million-people-in-the-united-states-and.html adresinden erişildi. 